Materiales de Construcción

Vol. 70, Issue 338, April-June 2020, e216

ISSN-L: 0465-2746

https://doi.org/10.3989/mc.2020.06919

\title{
Effects of waste sulfur content on properties of self-compacting concrete
}

\author{
A. Savića, S. Martinović $c^{b}$, M. Vlahović ${ }^{b} \bowtie$, T. Volkov-Husovićc \\ a. University of Belgrade, Faculty of Civil Engineering, Belgrade, Serbia \\ b. University of Belgrade, Institute of Chemistry, Technology and Metallurgy, Belgrade, Serbia \\ c. University of Belgrade, Faculty of Technology and Metallurgy, Belgrade, Serbia \\ $\triangle$ mvlahovic@tmf.bg.ac.rs
}

\begin{abstract}
Self-compacting concrete (SCC) contains fine mineral fillers such as limestone powder. The idea of this study was to partially replace limestone with waste sulfur since it is hydrophobic, insoluble in water and therefore chemically inert and to compare the properties of produced concrete samples. Fresh concrete properties included: slump-flow, $\mathrm{t}_{500}$, V-funnel time, L-box ratio, segregation ratio, density, and entrained air content. Hardened concrete was tested for compressive, flexural and bond strengths, ultrasonic velocity, dynamic elasticity modulus, dynamic Poisson's ratio, and microstructure. Flowability and segregation increased, while bulk density, compressive and flexural strength, dynamic elasticity modulus and ultrasonic velocity slight declined. Times $\mathrm{t}_{500}$ and $\mathrm{V}$-funnel time, L-box ratio and entrained air changed insignificantly. Considering that all properties should remain or improve in case of waste valorization and the criteria should set to satisfy requirements for SCC, this study proved that all mixtures can be used for structural applications.
\end{abstract}

KEYWORDS: Concrete; Mixture proportion; Mechanical properties; Microstructure; Modulus of Elasticity.

Citation/Citar como: Savić, A.; Martinović, S.; Vlahović, M.; Volkov-Husović, T. (2020) Effects of waste sulfur content on properties of self-compacting concrete. Mater. Construcc. 70 [338], e216 https://doi.org/10.3989/mc.2020.06919

RESUMEN: Efectos del contenido de residuos de azufre en las propiedades del hormigón autocompactante. El hormigón autocompactante (SCC, del inglés Self-compacting concrete) contiene cargas (fillers) minerales finas como polvo de piedra caliza. La idea de este estudio fue reemplazar parcialmente la piedra caliza por contenido de residuos de azufre, ya que es hidrófobo, insoluble en agua y, por lo tanto, químicamente inerte, y comparar las propiedades de las muestras de hormigón producidas. Las propiedades analizadas en el hormigón fresco incluyeron: flujo de asentamiento, $\mathrm{t}_{500}$, tiempo del embudo en V (V-funnel time), relación de caja en L (L-box ratio), relación de segregación, densidad y contenido de aire ocluido. En el hormigón endurecido se analizó la resistencia a compresión, flexión y adherencia, velocidad ultrasónica, módulo dinámico de elasticidad, coeficiente dinámico de Poisson y microestructura. La fluidez y la segregación aumentaron, mientras que la densidad aparente (bulk density), la resistencia a la compresión y la flexión, el módulo de elasticidad dinámica y la velocidad ultrasónica disminuyeron ligeramente. Los tiempos $\mathrm{t}_{500} \mathrm{y}$ el tiempo del embudo $\mathrm{V}$, la relación de la caja $\mathrm{L}$ y el aire ocluido cambiaron de manera insignificante. Considerando que al valorizar residuos, se deben conseguir propiedades similares o mejoradas, y que los criterios deben establecerse para satisfacer los requisitos de SCC, este estudio demostró que todas las mezclas se pueden utilizar para aplicaciones estructurales.

PALABRAS CLAVE: Hormigón; Proporción de mezcla; Propiedades mecánicas; Microestructura; Módulo Elástico.

ORCID ID: A. Savić (https://orcid.org/0000-0002-1777-6775); S. Martinović (http://orcid.org/0000-0001-8040-407X); M. Vlahović (https://orcid.org/0000-0002-7893-9101); T. Volkov-Husović (http://orcid.org/0000-0002-2667-5802)

Copyright: (C) 2020 CSIC. This is an open-access article distributed under the terms of the Creative Commons Attribution 4.0 International (CC BY 4.0) License. 


\section{INTRODUCTION}

Today's concept of building industry includes several approaches such are: acceptable physical and mechanical properties for specific applications, economic effects, material durability or lifespan, and ecological impact of these materials on the environment (1-3). Conventional concrete (CC) is usually placed by vibration to reduce the entrained air content and eliminate the possibility of cavities occurrence in contact with reinforcement and formwork. Very fine powders are added to CC mixtures as water reducing admixture, active additive or filler, and the viscosity-modifying admixture to densify the interface between aggregate and matrix. The development of super-plasticizers (chemical admixtures) allowed easier installing the concrete of stiffer consistency without any vibrations leading to the concept of highly flowable Self-Compacting Concrete (SCC) that spreads into place, easily fills framework and seals, encapsulates or wraps even the most congested reinforcement without segregation. Initial investigations and the term of SCC originated in the 1980s in Japan $(4,5)$, the first commercial use was in 1990 while the first important application was the building of pre-stressed concrete pylon for the cable-stayed bridge "Shin-Kiba Ohashi bridge" in 1991 (5). Since then, there has been a growing interest in SCC development. The most important advantage of SCC is the ability to flow into and fill spaces within the formwork under its own weight while maintains homogeneity during placement and compaction without vibration $(1,6-9)$. Its highly flowable nature can be attributed to careful mix design, usually replacing much of the coarse aggregate with fines and cement, and adding chemical admixtures. By excluding the vibration, internal segregation between solid particles and surrounding liquid phases are avoided, thus resulting in a less porous transition zone between the paste and aggregates and also higher compressive strength and durability, compared to the CC (10). Some disadvantages of SCC are a higher content of powdered components $(<0.125 \mu \mathrm{m})$, high cement portion, and usage of chemical additives. That increases cost for $20-60 \%$ comparing to the CC $(11,12)$. Also, the usage of super-plasticizers, higher content of powdered components, and a lower volume ratio of coarse aggregate can provoke more pronounced sensitivity of SCC, meaning reduced robustness that demands more frequent quality control (13). Therefore, furthering development should be optimization of price-performance ratio.

To overcome the disadvantages and reduce the overall production cost, it is necessary to use the inert or non-pozzolanic and hydraulic or pozzolanic material in the form of waste and recycling materials as a replacement for a binder, filler, and/ or chemical admixtures (14). Beside economic, there are also important environmental benefits by using industrial by-products. Also, data regarding the use of waste and cementitious materials in SCC was analyzed in previous study, show that industrial waste is among the most prominent (15). Namely, the design of SCC allows usage of industrial and building wastes in case of producing SCC with the same or better engineering properties $(6,14,16,17)$, while the purpose of using powdered waste industrial residues is to ensure sustainable production of SCC and to produce "green concrete" $(6,18-21)$. During the last decades, many researches were occupied with the valorization of technogenic wastes to reduce their negative effects on the environment. The most significant wastes used in SCC are: fly ash, blast furnace slag, rice husk, silica fume, building waste materials (14).

In the last decades, the availability of sulfur has considerably grown, mainly due to the current environmental restrictions regarding the petroleum and gas refining processes, which limit the maximum quantity of sulfur present at combustibles. Sulfur is therefore obtained as a by- product from processing natural gas and refining high-sulfur crude oils. The most common conversion method used in refineries is the Claus process. Extremely large quantities of waste sulfur are stored leading to more or less controlled disposal. According to US EPA, most of the $68 \times 10^{6}$ tons of sulfur produced in the world in 2012 was a by-product from refineries and other hydrocarbon processing plants (US EPA 2014) (22). Global production of sulfur will continue to increase, thus ensuring its continued availability in the future $(23,24)$.

Therefore, the development of new applications of sulfur becomes fundamental. Building materials come into the focus of interest at the time when industrial or municipal waste is becoming increasingly important as a potential raw material. One of the causes for that is the fact that the primary application of building materials has been constantly expanding, and therefore the alternative materials are also taking their place. Modification of conventional building materials is commonly realized using some of the secondary raw materials from various industrial processes. Generally, building materials are important acceptors for large quantities of various wastes since they can provide complete immobilization without degradation of their properties (25).

During the 1960 s, there was a remarkable investment in environmental protection against the discharge of sulfur into the surroundings, thus making sulfur a surplus commodity on the market, particularly in the United States and Canada. This was a crucial point, that made the interest in the usage of sulfur as a structural binder, to grow further.

Construction materials such as sulfur concrete and sulfur modified asphalt continue to receive more 
attention since they are environmentally friendly and cost-effective. Beginning in the 1970s, successful projects on sulfur concrete as a construction material have been carried out in different levels, mostly in North America, few and mainly research or test pilot projects in Europe, with only Denmark conducting commercial or industrial activities. Recent research activities on sulfur concrete as a construction material have been going on in Spain, Italy, and the Netherlands, while interest on medium scale industrial uses of sulfur concrete is in Poland. In South-East Asia, preliminary reports are indicating a growing interest in the use of sulfur concrete as a result of the increase of surplus sulfur from the refinery industry. Similar reports come from the Middle East (Saudi Arabia), South America (Chile) and Africa (South Africa), where attempts to use sulfur concrete were reported earlier, or are in progress (23).

The use of sulfur binder as a replacement for Portland cement to produce concrete is well-known for a long time. The obtained material, sulfur polymer concrete, has many advantages compared with the conventional Portland cement concrete especially concerning chemical resistance in aggressive acid and salt environments. Namely, there was evidence that no signs of degradation in more than 4 years of industrial testing in 50 process environments. This property of sulfur concrete can be attributed to sulfur (26-31). Considering our experience in synthesis of sulfur polymer concrete with sulfur as a by-product from natural gas and oil production (28-30), and the fact that elemental sulfur is almost inert and does not react with water under normal conditions, thus excluding the occurrence of sulfate attack, sulfur can be successfully used in the production of SCC. Nevertheless, there is data regarding sulfur solubility and stability in basic media. Sulfur is normally considered to be insoluble in water, in fact, the solubility of $\alpha-\mathrm{S}_{8}$ at $20^{\circ} \mathrm{C}$ is only $5 \mu \mathrm{g} / 1(32,33)$. Therefore, the idea of this study was to synthesize and characterize SCC modified with sulfur as a partial replacement of usual filler, limestone (both non-pozzolanic fillers).

The priority was not achieving high-strength concrete, but concrete of 20-30 MPa for the application in certain construction parts $(28-30,34)$.

\section{EXPERIMENTAL}

This study compares microstructural, fresh, and hardened properties of SCC with limestone as a filler (reference SCC) and SCC where certain portion of limestone is replaced by sulfur.

\subsection{Materials}

\subsubsection{Aggregate}

Natural aggregate originated from the river Danube was separated, and following fractions were used for SCC synthesis: I (0/4), II (4/8), and III (8/16). The particle size distribution of the aggregate determined according to the standard procedure (35) is shown in Figure 1. Contents of fine particles in fractions II and III were $1.84 \%$ and

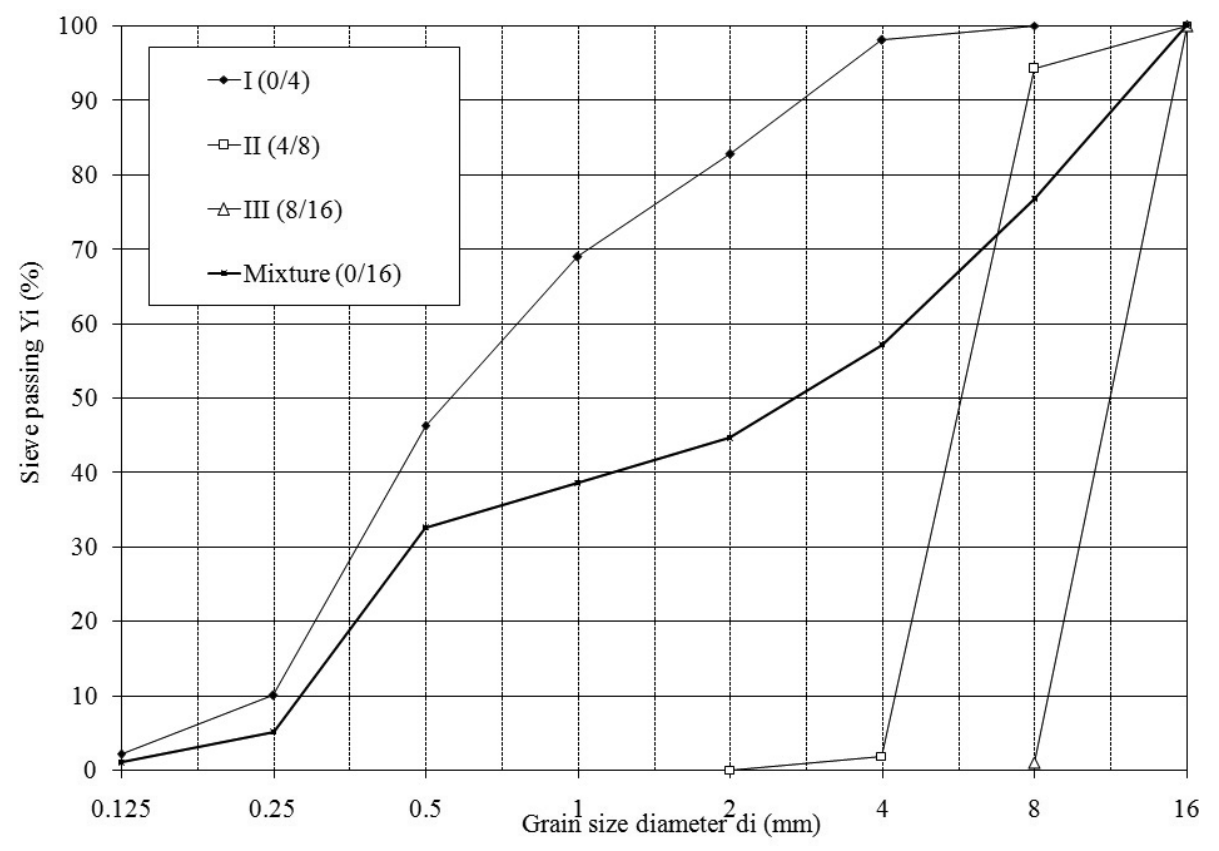

FIGURE 1. Particle size distribution of aggregate. 
$0.94 \%$, respectively, while the contents of coarser grains $(>4 \mathrm{~mm})$ in fractions I, II, and III were $1.96 \%, 5.81 \%$, and $0 \%$, respectively. Content of fine particles in fraction I determined according to the standard procedure (36), was $0.59 \%$ (particle size $<0.063 \mathrm{~mm}$ ) and $1.68 \%$ (particle size $<0.09 \mathrm{~mm}$ ). The grading curve of the fractions mixture is shown in Figure 1, as well.

Table 1 lists physico-mechanical and chemical properties of used aggregate fractions determined according to the standards (37-43). All determined properties meet the quality requirements (44-45).

The mass ratio of fractions II and III was determined on a laboratory test that made known the highest value of density for the mixture of these fractions in the dry compacted state, Figure 2. Consequently, the mass ratio of these fractions was adopted to be $1: 1$.

The content of fraction I in an aggregate mixture was determined based on the pilot mixtures and it was $31.8 \%$ of SCC total volume.

\subsubsection{Cement}

Cement without additives (CEM I 42.5R, Lafarge, Serbia) was used as a binder. Physicomechanical characteristics of cement are realized by standard procedures (46-48) shown in Table 2.

TABLE 1. Physico-mechanical and chemical properties of the aggregates

\begin{tabular}{lccc}
\hline & \multicolumn{3}{c}{ Fraction $(\mathbf{m m})$} \\
\cline { 2 - 4 } Property & $\mathbf{0 / 4}$ & $\mathbf{4 / 8}$ & $\mathbf{8 / 1 6}$ \\
\hline Resistance to frost $(\%)$ & 2.0 & 1.7 & 1.5 \\
Total sulfur as $\mathrm{SO}_{3}(\%)$ & 0 & 0 & 0 \\
Chloride content as $\mathrm{Cl}(\%)$ & 0 & 0 & 0 \\
Real density of aggregate grains $\left(\mathrm{kg} / \mathrm{m}^{3}\right)$ & 2640 & 2641 & 2642 \\
Bulk dry loose density $\left(\mathrm{kg} / \mathrm{m}^{3}\right)$ & 1667 & 1519 & 1493 \\
Bulk dry compacted density $\left(\mathrm{kg} / \mathrm{m}^{3}\right)$ & 1788 & 1621 & 1599 \\
Absorption $(\%)$ & 1.0 & 0.8 & 0.7 \\
Resistance to dynamic stress and abrasion by friction $(\%)$ & - & 25.9 & 29.2 \\
Cylinder crushing resistance $(\%)$ & - & 14.6 & 18.6 \\
\hline
\end{tabular}

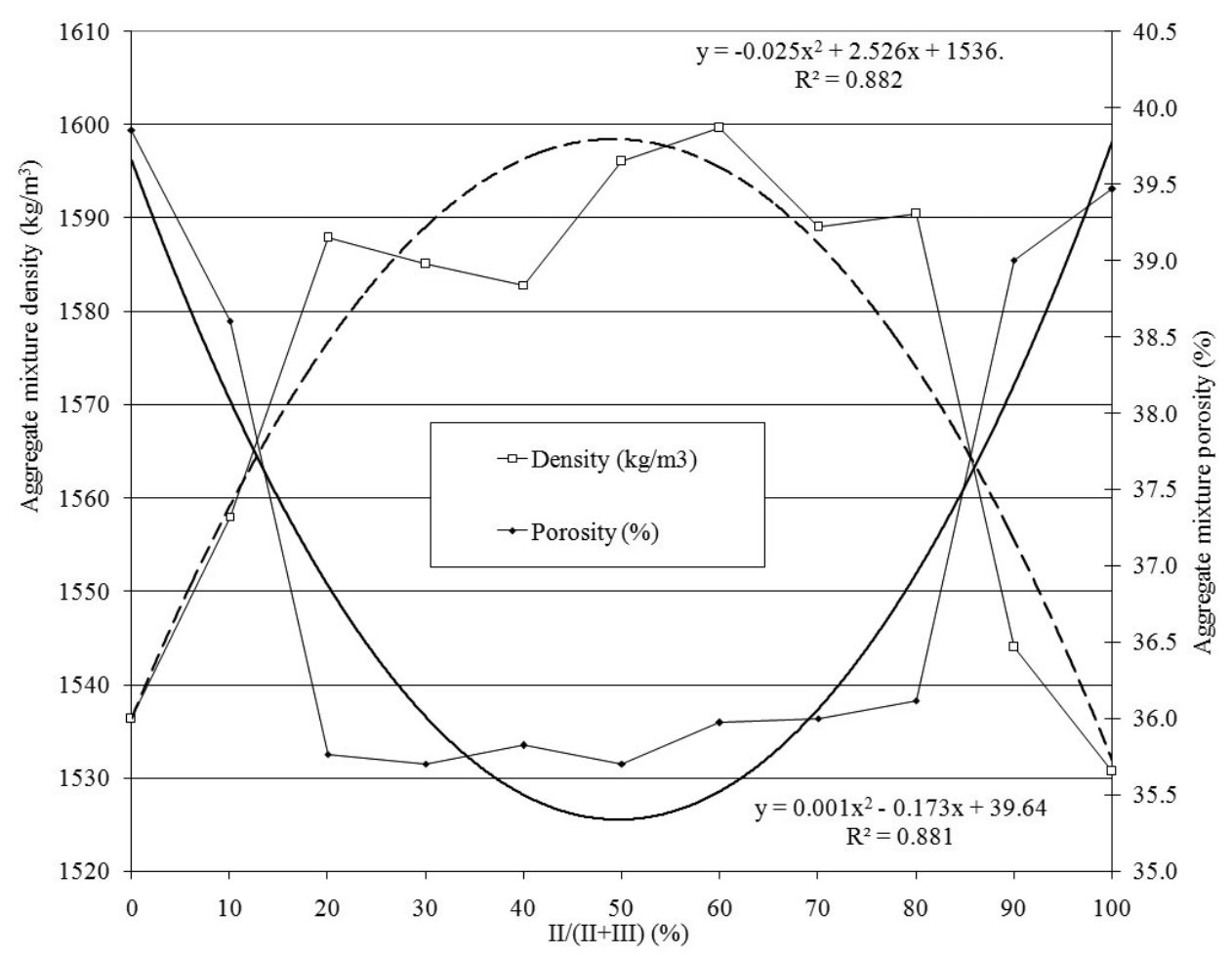

FIGURE 2. Density and porosity of two fractions mixture in various proportions II/(II+III). 
Chemical composition was obtained by standardized procedure (49) and given in Table 2.

\subsubsection{Limestone}

Limestone powder, carbonate with a medium grain size of $250 \mu \mathrm{m}$, (Granit Pescar, Ljig) was used as filler. Physico-mechanical properties of limestone are done on natural stone- limestone, which was ground to obtain limestone powder using standard procedures $(47,50-55)$ and given in Table 3. Chemical composition was provided by the producer and shown in Table 3.

\subsubsection{Sulfur}

Secondary sulfur used as a partial substitution for usual mineral filler, limestone, originates from the oil refining process by Claus's procedure in the Oil Refinery Pancevo and its purity was $99.9 \%$. The density of sulfur was $2050 \mathrm{~kg} / \mathrm{m}^{3}$ and was done by standard procedure (50) while the specific surface area $2600 \mathrm{~cm}^{2} / \mathrm{g}$ was realized by Blaine method. Elemental sulfur is hydrophobic and insoluble in water under normal conditions (26-27, 32-33).

\subsubsection{Super-plasticizer}

A new generation of chemical admixture, polycarboxylate based super-plasticizer, Glenium Sky 690 (BASF Construction Chemicals, Italy), was used to provide self-compacting abilities and enhance flowability of concrete. Its properties were provided by the producer and shown in Table 4.

\subsection{Mix proportion and test procedure}

SCC mixes were designed based on preliminary experiments that included variations of composition and obtained fresh and hardened concrete properties. Compositions of five SCC mixtures are given in Table 5. The reference concrete series (E) was made with limestone powder as filler. In series S2, S5, S10, and S20, limestone was partially replaced with

TABLE 2. Physico-mechanical properties and chemical composition of cement

\begin{tabular}{|c|c|c|c|c|c|c|c|c|c|}
\hline \multicolumn{5}{|c|}{ Physico-mechanical properties } & \multicolumn{3}{|c|}{ Standard procedure } & & Value \\
\hline \multicolumn{5}{|c|}{ Sieve $0.09 \mathrm{~mm}$ residue $(\%)$} & & \multicolumn{2}{|c|}{ (46) } & \multicolumn{2}{|r|}{0.5} \\
\hline \multicolumn{5}{|c|}{ True density $\left(\mathrm{kg} / \mathrm{m}^{3}\right)$} & & & & \multicolumn{2}{|r|}{3040} \\
\hline \multicolumn{5}{|c|}{ Loose density $\left(\mathrm{kg} / \mathrm{m}^{3}\right)$} & & & & \multicolumn{2}{|r|}{890} \\
\hline \multicolumn{5}{|c|}{ Compacted density $\left(\mathrm{kg} / \mathrm{m}^{3}\right)$} & & & & \multicolumn{2}{|r|}{1440} \\
\hline \multicolumn{5}{|c|}{ Specific area-Blaine $\left(\mathrm{cm}^{2} / \mathrm{g}\right)$} & \multicolumn{3}{|c|}{ (47) } & \multicolumn{2}{|r|}{4240} \\
\hline \multicolumn{5}{|c|}{ Standard consistency $(\%)$} & \multicolumn{3}{|c|}{$(48)$} & \multicolumn{2}{|r|}{27.8} \\
\hline \multicolumn{10}{|c|}{ Chemical composition (49) } \\
\hline Component & $\mathrm{CaO}$ & $\mathrm{SiO}_{2}$ & MgO & $\mathrm{Al}_{2} \mathrm{O}_{3}$ & $\mathrm{Fe}_{2} \mathrm{O}_{3}$ & $\mathrm{~K}_{2} \mathrm{O}$ & $\mathrm{Na}_{2} \mathrm{O}$ & $\mathrm{TiO}_{2}$ & $\mathrm{SO}_{3}$ \\
\hline Value $(\%)$ & 61.64 & 21.21 & 2.22 & 4.81 & 2.13 & 1.11 & 0.33 & 0.18 & 6.37 \\
\hline
\end{tabular}

TABLE 3. Physico-mechanical properties and chemical composition of limestone

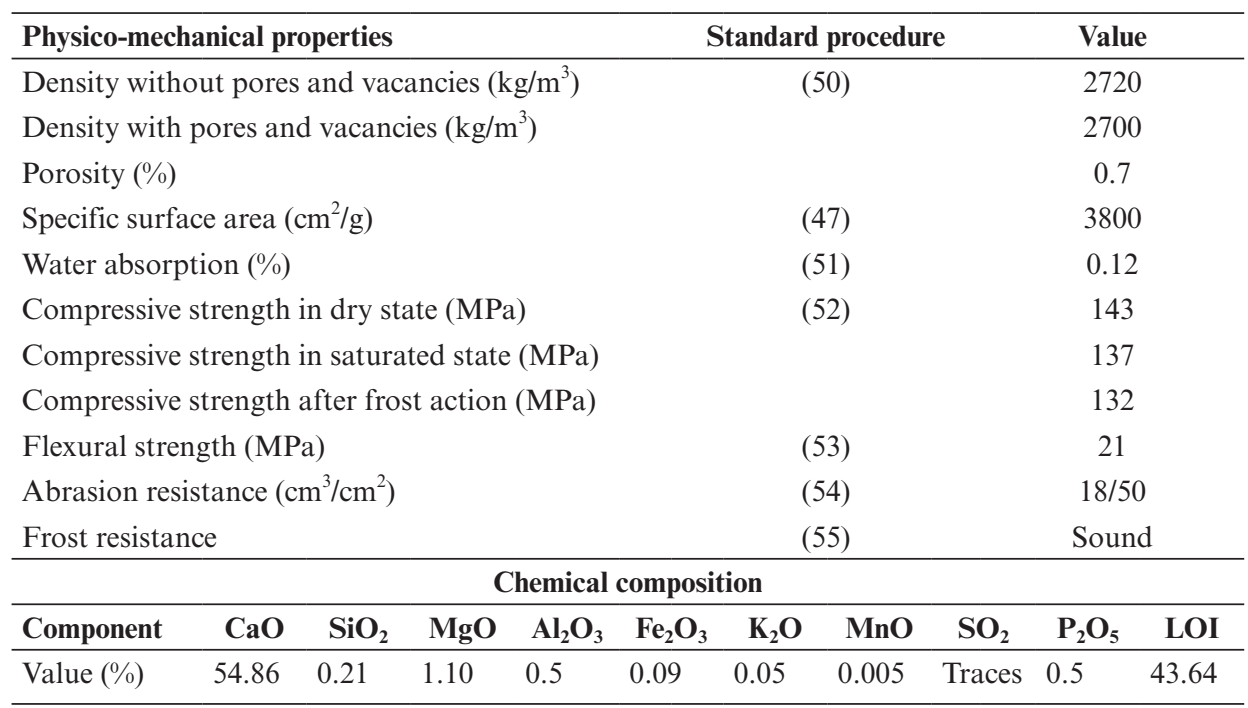


TABLE 4. Physico-mechanical properties of super-plasticizer

\begin{tabular}{lc}
\hline Physico-mechanical properties & Value \\
\hline Density at $20{ }^{\circ} \mathrm{C}\left(\mathrm{kg} / \mathrm{dm}^{3}\right)$ & 1.06 \\
Viscosity at $20{ }^{\circ} \mathrm{C}(\mathrm{mPa} \cdot \mathrm{s})$ & $30-200$ \\
Solid particles content $(\%)$ & 26 \\
$\mathrm{pH}$ & $5-8$ \\
Chloride ion content $(\%)$ & 0.01 \\
Alkali content (as $\mathrm{Na}_{2} \mathrm{O}$ equivalent $)(\%)$ & 0.26 \\
\hline
\end{tabular}

TABle 5. Compositions of SCC mixes

\begin{tabular}{lrrrrr}
\hline & \multicolumn{5}{c}{ Series } \\
\cline { 2 - 6 } Concrete component & \multicolumn{1}{c}{ S } & S2 & S5 & S10 & S20 \\
\hline Limestone powder $\left(\mathrm{kg} / \mathrm{m}^{3}\right)$ & 220 & 215.6 & 209 & 198 & 176 \\
Ground sulfur $\left(\mathrm{kg} / \mathrm{m}^{3}\right)$ & 0 & 4.4 & 11 & 22 & 44 \\
Superplasticizer $\left(\mathrm{kg} / \mathrm{m}^{3}\right)$ & & & 7.6 & & \\
Water to cement ratio $(\mathrm{w} / \mathrm{c})$ & & & 0.482 & \\
Fluid & & & \\
\end{tabular}

*Fluid-sum of water and superplasticizer; Powder- sum of cement, limestone and ground sulfur.

sulfur ( $2 \%, 5 \%, 10 \%$, and $20 \%$, respectively). Water content and superplasticizer dosage were kept constant for all mixtures.

In order to provide mixes flowability as well as homogeneity and uniformity of concrete properties, the following procedure was applied: mixing of coarse (II and III fractions) and fine (I fraction) aggregates for $60 \mathrm{~s}$, addition of cement and mixing for $30 \mathrm{~s}$, and then dosage of water and super-plasticizer with an additional mixing of 270 s. For this preparation, laboratory mixer with a capacity of 60 1 , fixed drum, and paddles at the vertical axel was used. SCC series were made at the ambient temperature $\left(20-22^{\circ} \mathrm{C}\right)$. After preparation, fresh concrete tests were performed according to the standard procedures recommended by EFNARC committee (8). Then, fresh concrete was poured into the moulds, de-moulded after 24 hours and cured until the hardened concrete testing day. For the purpose of various testing, cubes $(10 \mathrm{~cm})$, prisms $(12 \times 12 \times 36 \mathrm{~cm})$, and plates $(50 \times 50 \times 8 \mathrm{~cm})$ were prepared.

\subsection{Test procedure}

All applied methods were standard procedures for testing of the initial components, fresh and hardened concrete, according to the European Guidelines for SCC recommendations (8).

The effects of limestone replacement on the fresh SCC properties were evaluated by the following tests: flowability (Slump-Flow, $\mathrm{t}_{500}$, V-Funnel time), L-box (passing ability $\left(\mathrm{H}_{2} / \mathrm{H}_{1}\right)$ ), segregation resistance, density, content of the entrained air. Standard procedures (56-60) are applied for determining fresh SCC properties, respectively.

Investigations on the hardened SCC included: compressive, flexural and bond strength, dynamic modulus of elasticity, dynamic Poisson's ratio, ultrasonic pulse velocity, according to standardized procedures (61-65).

Dynamic elasticity modulus was measured using ERUDITE device, based on determining the resonance frequency of concrete prisms exposed to the longitudinal waves. The samples were subjected to ultrasonic velocity measurement by PUNDIT testing device. Both measurements were realized on the fixed prismatic samples $(12 \times 12 \times 36 \mathrm{~cm}$ with measurements in the direction of the sample length of $36 \mathrm{~cm}$ ) from the age of 7 days until 28 days, with one additional at 180 days.

The microstructure of $\mathrm{SCC}$ was monitored using a scanning electron microscope (SEM) JEOL JSM-6610LV that achieves high-resolution images at magnification range up to $100000 \mathrm{x}$. Besides the reference sample (E), two samples of S20 were also selected. One S20 sample was prepared by polishing and another was not polished to avoid the induced surface damage. This especially refers to the presence of softer sulfur grains, which can be damaged or even removed during the polishing.

Prior to SEM analysis, the samples were cleaned from dust, fibers, paper, untied or loosely bound particles, greasy parts, fingerprints and the like, using petroleum ether and then held several minutes in ultrasonic cleaning bath and dried under the lamp. Before SEM recording, the samples were prepared by steaming a thin layer (15-25 nm) of carbon (polished samples) or gold (unprepared sample).

The true densities of the hardened concrete samples E and S20 were conducted by helium pycnometer using the ATC Helium Pycnomatic (Thermo Scientific) device with double temperature measuring point. Measuring was done exactly at the temperature of $20.00{ }^{\circ} \mathrm{C} \pm 0.01$, while the fluid helium was of purity 5.0.

Mercury porosimetry (true porosity) measurements were performed on a high pressure unit PASCAL 440 (Thermo Scientific) in CD3-N type dilatometer in the pressure range $0.1-200 \mathrm{MPa}$. Two intrusion-extrusion runs were conducted, one after the other. A SOLID Software System PC interface was used for automatic data acquisition and textural parameter calculation.

\section{RESULTS AND DISCUSSION}

\subsection{Properties of fresh SCC}

According to the (8), a concrete mixture can be classified as SCC if the requirements for filling, passing, and segregation resistivity of the fresh concrete 
are fulfilled. For this purpose, fresh SCC properties were determined according to the standard procedures and results are shown in Table 6.

A method for quantifying SCC flowing characteristics of a fresh mix in unconfined conditions is a slump-flow test (SF). As can be seen, the slump flow diameters of the mixes with sulfur were higher than in the reference mixture $(E)$. Generally, slump-flow values are in the range from 761 to $820 \mathrm{~mm}$ which means that they belong to a desirable range. More precisely, all series satisfy the requirements for SCC and fall into the category of SF3 (760-850 mm), according to the EFNARC (8). The concrete mixture of this slump flow class is suitable for vertical applications in case of highly congested rebars, structures with complex shapes, and for fulfilling difficult-to-reach areas inside the formwork (8). The reference mix exhibited the lowest slump flow value.

The relationship between slump-flow and free water content were studied earlier showing that the slump-flow value increases with the content of free water until the saturation (66). Starting with this assertion, the following assumption is possible. A noticeable positive effect of sulfur on slump-flow may be attributed mainly to its lower Blaine specific surface area $\left(2600 \mathrm{~cm}^{2} / \mathrm{g}\right)$ compared to limestone $\left(3800 \mathrm{~cm}^{2} / \mathrm{g}\right)$, but also to sulfur hydrophobicity. Namely, the higher value of the Blaine specific surface area of limestone compared with powdered sulfur requires more water to reach a certain slump flow value. This has been investigated previously, for instance, according to the (8), Blaine specific surface changes the water demand of the mix. Since the water content is constant in all mixtures, the slump flow of the reference mixture is the lowest (67). Furthermore, hydrophobicity has a similar effect on slump flow. Sulfur additionally improves the workability of the mix since there is almost no absorption of water by the sulfur, thus increasing the free water content of the mixes reducing yield stress and friction among the particles and thus providing better flowability. Contrary, limestone shows water absorption of $0.12 \%$, so with increasing limestone content, the water/cement ratio will decrease as well as the slump flow values. Precisely, such a mixture requires higher water content to achieve a certain flowability.

According to the results, the best flowability of mixtures S2 and S5 indicates an optimal portion for replacing limestone with sulfur $(14,68)$.

Viscosity and filling ability of SCC determined indirectly by measuring the flowing time $\mathbf{t}_{\mathbf{5 0 0}}$ during the slump-flow test and the efflux time $\mathbf{t}_{v}$ during the V-funnel test demonstrate negligible increment or decrement compared to the reference sample. Lower values of $t_{500}$ indicate improved viscosity of the mixture. However, all series fulfill SCC viscosity requirements and can be categorized in the viscosity class of VS2 with $t_{500}>2 \mathrm{~s}(8)$. Since differences among $t_{500}$ values of all series are less than one second, it is obvious that partial replacement of limestone with sulfur has no significant influence on viscosity. Substituting limestone with sulfur provides satisfactory rheological properties with flow time values that indicate relatively high viscosity probably because of smooth surface texture and sulfur hydrophobicity. S2 mixture has the lowest value of the $t_{500}$, very close to the reference one, while other mixtures show an increment of the flow time value with sulfur content increase. Considering the validation, all measured $t_{500}$ values are valid for the class of $<3.5 \mathrm{~s}$, with the repeatability of $0.66 \mathrm{~s}$ and the reproducibility of $0.88 \mathrm{~s}$. Similarly, analysis of the sulfur content influence on $\mathrm{t}_{\mathrm{v}}$ values shows that their mutual differences are less than $2.5 \mathrm{~s}$ that is in the range of repeatability, so it can be valid for one series (repeatability of $2.6 \mathrm{~s}$ and reproducibility of $3.9 \mathrm{~s}$ for the reference mix). Namely, the V-funnel time for the mixtures with sulfur did not show significant differences depending on the reference mixture. All mixtures satisfied the requirement of SCC limit and can be qualified as SCC viscosity class of VF2 according to EFNARC (8).

TABle 6. Properties of fresh SCC

\begin{tabular}{lccccc}
\hline & \multicolumn{5}{c}{ Series } \\
\cline { 2 - 6 } Property & E & S2 & S5 & S10 & S20 \\
\hline Slump-flow $(\mathrm{mm})$ & 761 & 820 & 820 & 780 & 775 \\
Time $_{500}(\mathrm{~s})$ & 2.62 & 2.59 & 2.84 & 3.42 & 3.07 \\
V-funnel time $\mathrm{t}_{\mathrm{v}}(\mathrm{s})$ & 9.73 & 8.21 & 10.48 & 8.87 & 9.21 \\
L-box $(\mathrm{H} 2 / \mathrm{H} 1)$ & 0.97 & 0.98 & 0.98 & 0.96 & 0.96 \\
Segregation resistance $(\%)$ & 3.5 & 4.3 & 3.8 & 4.2 & 3.6 \\
Fresh concrete density $\left(\mathrm{kg} / \mathrm{m}^{3}\right)$ & 2397 & 2394 & 2387 & 2381 & 2375 \\
Content of entrained air $(\%)$ & 1.9 & 1.2 & 1.2 & 1.7 & 1.9 \\
\hline
\end{tabular}

$\mathrm{t}_{500}$ - time required for spreading; $\mathrm{t}_{\mathrm{v}}$ - V-funnel time; $\mathrm{H} 1$ and $\mathrm{H} 2$-heights at the beginning and at the end of the horizontal part of L-box, respectively 
Passing ability (PA) that evaluates the ability of SCC to flow around obstructions was measured according to the standard test [57]. Based on the criteria specified in this standard for the opening with three smooth steel bars of $12 \pm 0.2 \mathrm{~mm}$ in the L-box test, all mixtures have the blocking ratios between 0.96 and 0.98 and achieve the class PA2 (H2/H1> $0.8)$, Table 6. Namely, all obtained PA values are in the range that did not show any tendency of blockage and achieved sufficient resistance to segregation around congested reinforcement area. The changes in PA of mixtures with sulfur comparing with the reference one show increase for $1 \%$ in case of lower sulfur content (S2 and S5) and decrease of 1\% in case of higher sulfur content (S10 and S20). This means that there is a slight workability increase in the samples with lower sulfur content and its slight decrease in the samples with higher sulfur content. As a general observation, there are no significant changes in PA depending on sulfur content, since all results are in the range of \pm 0.01 , indicating a similar behavior of the samples.

Segregation resistance (SR) is very important characteristic of SCC since it has a pronounced influence on the in-situ properties of hardened concrete. Determination of segregation resistance was measured according to the sieve segregation test [58] and expressed as a portion of segregated particles in percentage. The segregation ratio of tested SCC mixtures ranged from 3.5 to $4.3 \%$, Table 6 , and according to EFNARC (8), all mixtures belong to the class of SR $2 \leq 15 \%$. It is evident that segregation ratios of the mixtures with sulfur increase in relation to the reference one by up to $22.9 \%$. Results clearly indicate a certain increase in segregated portion probably due to larger amount of hydrophobic sulfur and therefore higher content of free water and hence lower cohesion.

The density of fresh concrete is lower in mixtures with sulfur compared with the reference, and its values decrease with increasing sulfur portion, Table 6 . The dependence of fresh concrete density and content of limestone substituted with sulfur is linear with the excellent correlation coefficient, Figure 3. The decline can be explained by lower sulfur density compared with limestone. More precisely, this decline is quite small and amounts $0.9 \%$ for the replacement of $20 \%$ limestone with sulfur. Based on the linear interpolation of the fresh SCC density, the following Equation [1] is obtained:

$$
\gamma=-1.11 \cdot p+2394\left(R^{2}=0.926\right)
$$

where: $\gamma\left(\mathrm{kg} / \mathrm{m}^{3}\right)$ is fresh concrete density, $\mathrm{p} \mathrm{( \% )}$ is a sulfur portion in total filler mass. This correlation complies with the mass equation, for the components used and their densities.

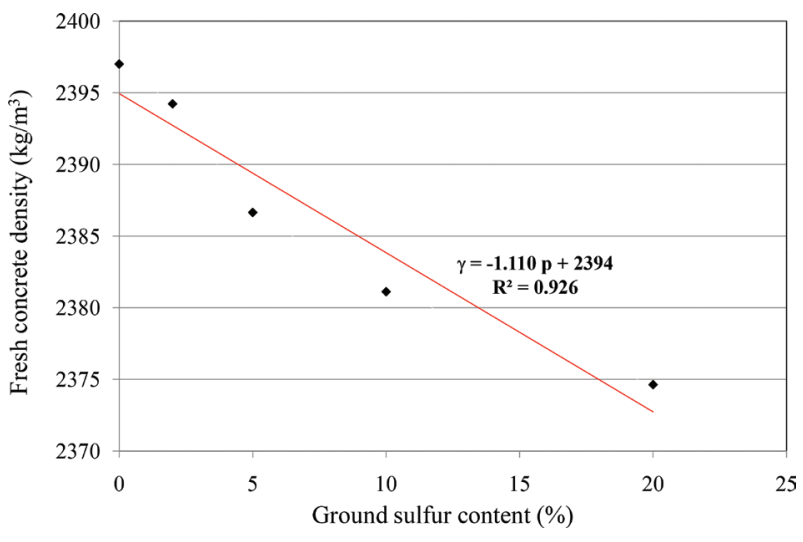

Figure 3. Density of fresh SCC depending on the ground sulfur portion in total filler mass.

The content of entrained air did not significantly change with the sulfur content increase, Table 6. However, sulfur improved the fresh SCC quality because of decreasing the entrapped air content. Namely, air content in fresh mixtures with $2 \%$ and $5 \%$ of sulfur decreased by $36.8 \%$ compared with the reference sample and $10.5 \%$ compared with the mixture with $10 \%$ of sulfur. Air content in mixture with $20 \%$ of sulfur was the same as in the reference one. This may be attributed to the sulfur content and thus increased free water content and better filling ability of concrete mixes with sulfur. Figure 4 indicates a good correlation $\left(\mathrm{R}^{2}=0.97\right)$ between slumpflow and entrained air content for fresh mixtures. This is in accordance with the general concept for normally vibrated concrete (NVC) that agitation of stiffer consistency entrains higher air amount.

According to the results, all mixes satisfied the EFNARC limits for fresh SCC properties.

\subsection{Properties of hardened SCC}

\subsubsection{Compressive strength}

Compressive strength test measurements were done on three samples (cubes of $10 \mathrm{~cm}$ edge length) for each composition and curing age, while the average values are shown in Table 7. As expected, strength was weakened with the increase of replaced limestone portion with sulfur while it was enhanced by concrete ageing. So the lowest value of $44.1 \mathrm{MPa}$ was developed in the specimen with the highest replacement percentage (S20) at the age of 3 days, while the highest value of $62 \mathrm{MPa}$ was reached after 28 days for E. Compressive strength of tested SCC samples during the ageing is given in Table 7. It is evident that the higher replacement ratio negatively affects compressive strength, more precisely strength decreases up to $12 \%$ regarding the reference sample. Strength decrease depends both on the portion of limestone replaced with sulfur and ageing period, 
TABLE 7. Compressive strength changes of tested SCC samples during the ageing

\begin{tabular}{lcccc}
\hline & \multicolumn{4}{c}{$\begin{array}{c}\text { Compressive strength (MPa) } \\
\text { at time of aging (days) }\end{array}$} \\
\cline { 2 - 5 } Sample & $\mathbf{3}$ & $\mathbf{7}$ & $\mathbf{1 4}$ & $\mathbf{2 8}$ \\
\hline E & 48.8 & 53.9 & 58.3 & 62.0 \\
S2 & 48.3 & 53.0 & 58.0 & 61.2 \\
S5 & 46.1 & 52.0 & 58.0 & 62.2 \\
S10 & 46.1 & 49.2 & 53.4 & 54.8 \\
S20 & 44.1 & 47.9 & 53.0 & 54.6 \\
Standard Deviation (MPa) & 1.90 & 2.55 & 2.69 & 3.90 \\
Mean & 46.7 & 51.2 & 56.1 & 59.0 \\
Maximum & 48.8 & 53.9 & 58.3 & 62.2 \\
Minimum & 44.1 & 47.9 & 53.0 & 54.6 \\
Median & 46.1 & 52.0 & 58.0 & 61.2 \\
\hline
\end{tabular}

probably due to the two effects. Firstly, sulfur has a lower hardness value (1.5-2) than limestone (3) in the Mohs scale, so SCC with higher sulfur content would have lower strength.

Secondly, explication of obtained results regarding the compressive strength should be based on considering the facts that the compressive strength of any concrete is usually lower for the lower density (69), while connected to lower porosity as well (70). Accordingly, the lower compressive strength of the samples with sulfur can be explained by the presence of a certain amount of waste sulfur. This is because the used waste sulfur has both lower density and lower mechanical properties, in comparison to the used limestone. Also, the results of true density measurements of hardened concrete samples show that the samples with sulfur have lower true density comparing with the samples prepared only with the limestone.

Thirdly, it is well known that lower strength is obtained in a higher w/c ratio. Contents of water and cement are the same in all prepared mixtures. However, waste sulfur that is sulfur in its elemental form, almost does not absorb water, unlike limestone. Therefore, the content of free water in such fresh mixtures with sulfur (and thus the effective w/c ratio) is higher compared to the mixtures with limestone (26-29). According to the current knowledge and studies of concrete technology, the greatest impact on the concrete strength is the water/cement factor of the fresh concrete mixture. Namely, concrete with a lower water/cement factor will have higher strength than one with a higher water/cement factor $(71,72)$. In this case, mixtures with sulfur have lower compressive strength. Similarly to the use of porous aggregates, such as recycled concrete aggregate (73), difference in porosity of the used filler directly affects the water volume available for the chemical reactions, i.e., lower the porosity of filler, higher the 'free' water content, and, consequently,

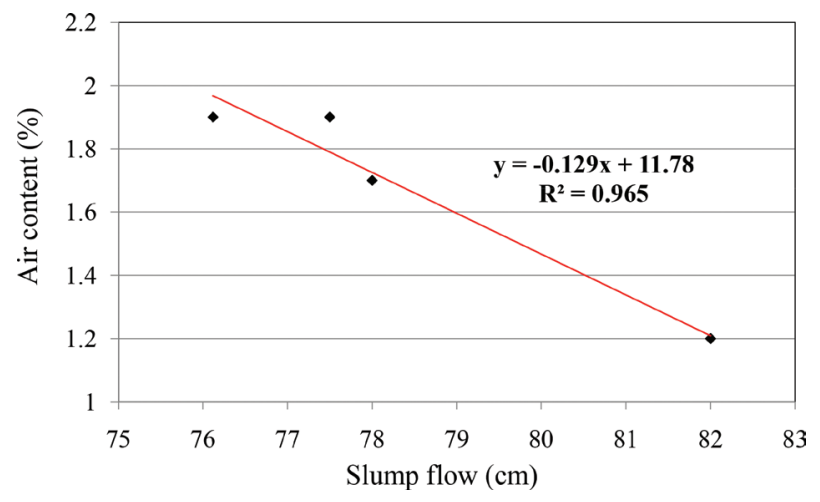

Figure 4. Correlation between slump flow and entrained air content of the SCC with sulfur.

the higher effective water to cement ratio, and finally lower compressive strength (74).

Compressive strength enhanced by ageing from $15 \%$ to $26 \%$. It is noticeable that the strength increase with age is higher in the reference sample and the samples with a small percentage of limestone replacement, while in the samples with 10 and $20 \%$ of replaced limestone, the strength increase did not exceed $15.88 \%$. Also, compressive strength change during ageing was not directly proportional to the increase of limestone replacement. Namely, strength decrease for SCC with $10 \%$ and $20 \%$ of sulfur was almost similar at the late-age stages. More precisely, differences in strength decrease between S10 and S20 are becoming smaller with the increasing ageing time. In addition, the strength values are probably influenced by the filling effect of different filler particles and their various specific surface areas. Therefore, the higher strength of the specimens without sulfur or with a lower portion of replaced limestone with sulfur can be attributed to higher specific surface area of limestone than sulfur.

Figure 5 shows the values of the compressive strength of each sample with sulfur divided by the value of compressive strength of the reference sample at a certain age.

As can be seen from Figure 5, all samples containing sulfur reached at least $88 \%$ of the corresponding strength of the reference sample, at the same ages. Two groups can be distinguished. The first group is consisted of samples S2 and S5 which reached almost the same values of compressive strength of the reference E ( $94 \%$ or more of the reference). The second group represents samples S10 and S20, with a substantial drop of compressive strength of the reference $\mathrm{E}$ (a drop of 6-12\%).

\subsubsection{Flexural and tensile bond strength}

Flexural strength was measured according to the three-point loading test in the middle of the span, at the age of 180 days. The test was carried out on three 
$12 \times 12 \times 36 \mathrm{~cm}$ specimens, while the average values of three measurements are shown in this study.

The bond strength determined by pull-off strength test is often used for successful evaluation of concrete resistance and verification of the adhesion strength of the concrete repairing structures (75). The tensile bond strength was not the issue in this study because such strength of used adhesive was several times greater than the bond strength between aggregates and cement paste in the tested hardened concrete. It should be emphasized that in all conducted tests, the failure occurred usually inside the bulk of concrete, neither in the adhesive nor at the contact of adhesive and concrete. Therefore, obtained strength values refer to the strength of the bond among the concrete components bearing in mind the presence of different sulfur content. Quality of SCC was determined at the age of 180 days, on the $50 \times 50 \times 8 \mathrm{~cm}$ plates.

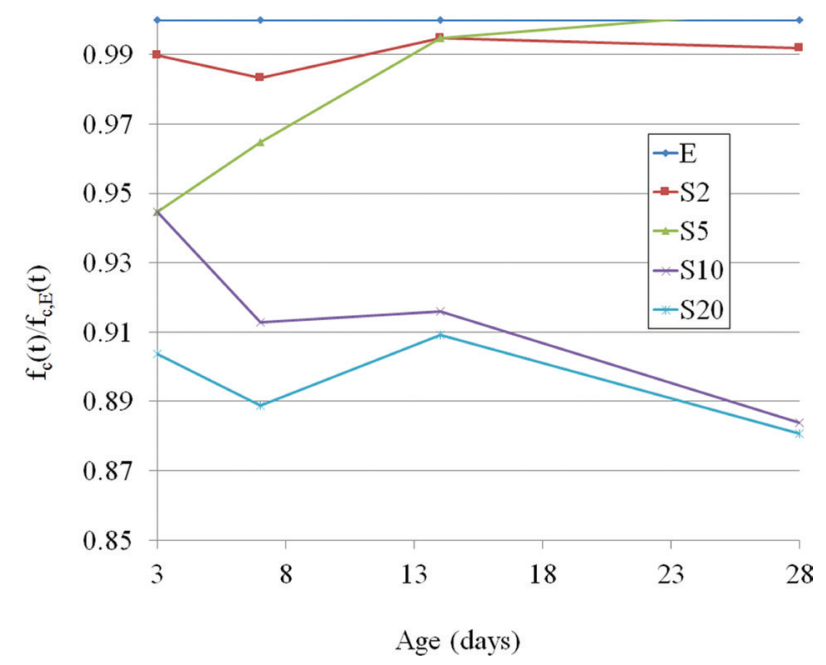

FIGURE 5. Relationship between compressive strength of the sample with sulfur versus the reference strength with ageing time.
Test dollies of two different diameters, Ø20 $\mathrm{mm}$ and $\varnothing 50 \mathrm{~mm}$, were applied. Five tests/measurements were conducted for each series and both dolly diameters, while the average values are presented in this study.

Flexural strength values were in the range of 6.9 (S20) and 10.5 MPa (E), while the adhesion strength values were within the limits of $5.53 \mathrm{MPa}(\mathrm{E})$ and $7.50 \mathrm{MPa}(\mathrm{S} 10)$ in the case of $\varnothing 20$ dolly and within the limits of 5.77 $\mathrm{MPa}(\mathrm{E})$ and $6.28 \mathrm{MPa}(\mathrm{S} 10)$ for the $\varnothing 50$ dolly.

Diagrams in Figure 6 show the decrease of flexural and increase of adhesion or bond strength of SCC with sulfur in relation to the reference SCC.

Flexural strength decreases for samples with sulfur in comparison to the reference sample from 18.1 $\%(\mathrm{~S} 2)$ to $34.3 \%$ (S20), Figure 6 a). It can be concluded that this decrease is directly, almost linearly, proportional to the increase of limestone replacement by sulfur. Similarly to compressive strength, flexural strength decrement of SCC with sulfur in comparison with SCC without sulfur can be explained by higher effective water to cement ratio and lower sulfur hardness.

Figure 6 b) shows a change in adhesion strength of SCC with sulfur compared to the reference sample. Results of the pull-off test show that the increase of adhesion strength is lower for the samples with higher content of sulfur for both dolly diameters. It can be concluded that the use of sulfur has no negative influence on the adhesive strength regardless of the used dolly diameter. In addition, bond strength increment is more pronounced for the dolly diameter of Ø20 compared to Ø50.

\subsubsection{Ultrasonic pulse velocity tests (UPVT)}

Ultrasonic pulse velocity measurements provide important information about the structural, mechanical, anisotropic, and elastic properties of a
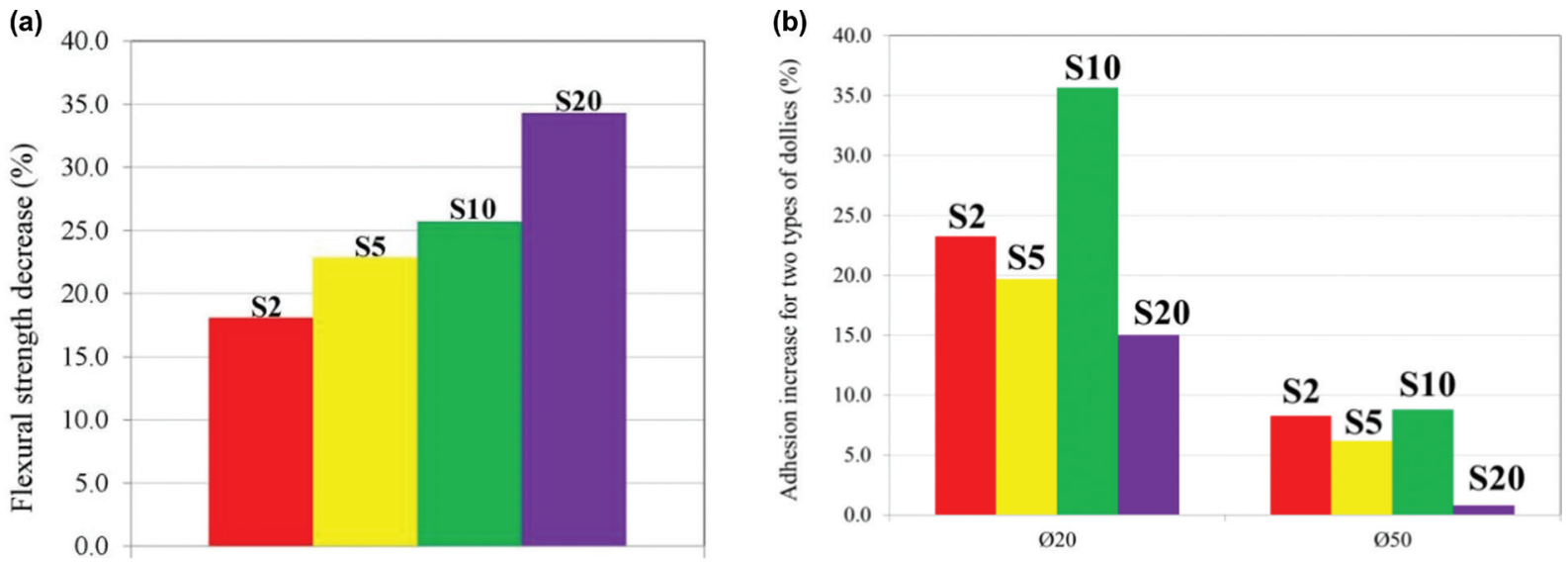

FIGURE 6. Flexural and adhesion strength changes of SCC: a) with sulfur, b) reference. 
medium it passes through. Since the theory proves that ultrasonic pulse travels with lower velocity through the material of higher porosity and lower density (76-78), measuring ultrasonic velocity can be used for monitoring changes in the materials structure such are homogeneity, existence and evaluation of cracks, voids, holes and pits, estimation of compressive strength and determination of elastic modulus.

Table 8 shows that the increasing sulfur content induces the decrease of dynamic elasticity modulus $\left(E_{d}\right)$ for all ageing stages while these values are increasing during the ageing per each series. It can be observed that $E_{d}$ values are in the range of 40 and $44.12 \mathrm{GPa}$. However, a more comprehensive approach of dynamic elasticity modulus changes with adding sulfur can be shown through the decrement in comparison with the reference, Table 8. It is obvious that with increasing the sulfur content, that decrement is becoming higher. Changes between those two dynamic elasticity moduli were from $0.1 \%$ to $5.7 \%$. Depending on the amount of replaced limestone, the largest decrement of elasticity modulus compared with the reference sample E was observed in S20 sample (2.8-5.7\%) and the smallest in S2 sample (0.1-1.9\%). Mutual variations among $E_{d}$ values of the SCC with sulfur were characterized as relatively small, ranging $0.1-5.1 \%$ compared to the reference sample.

The analysis of $E_{d}$ changes shows a similar trend as compressive strength, $\mathrm{E}_{\mathrm{d}}$ decrease with the sulfur content increase and $E_{d}$ increase with the ageing. This behavior can be explained not only by the influence of less hard and hydrophobic sulfur but also with entrapped air content. Namely, the concrete component with lower hardness, higher water content or w/c ratio, as well as higher entrapped air content would induce lower $\mathrm{E}_{\mathrm{d}}$ values. Moreover, fresh concrete investigation shows that entrapped air content decreases with increased sulfur content.

TABLE 8. Dynamic elasticity modulus of tested SCC samples during the ageing

\begin{tabular}{lccccc}
\hline & \multicolumn{5}{c}{ Ed (GPa) at time of aging (days) } \\
\cline { 2 - 6 } Sample & $\mathbf{7}$ & $\mathbf{1 4}$ & $\mathbf{2 1}$ & $\mathbf{2 8}$ & $\mathbf{1 8 0}$ \\
\hline E & 41.6 & 42.2 & 42.8 & 43.4 & 44.1 \\
S2 & 40.8 & 42.1 & 42.6 & 43.4 & 43.8 \\
S5 & 40.8 & 42.1 & 42.6 & 43.4 & 43.8 \\
S10 & 40.0 & 41.4 & 41.6 & 42.2 & 42.5 \\
S20 & 40.2 & 41.0 & 41.4 & 41.5 & 41.6 \\
Standard Deviation $(\mathrm{MPa})$ & 0.63 & 0.50 & 0.61 & 0.82 & 1.07 \\
Mean & 40.6 & 41.7 & 42.1 & 42.66 & 43.16 \\
Maximum & 41.6 & 42.2 & 42.8 & 43.4 & 44.1 \\
Minimum & 40.0 & 41.0 & 41.4 & 41.5 & 41.6 \\
Median & 40.4 & 41.8 & 42.0 & 42.8 & 43.8 \\
\hline
\end{tabular}

Therefore, it can be assumed that the influence of the entrapped air is not dominant but the filler hardness and free water content.

Since SCC has a uniform consistency, compressive strength and dynamic modulus of elasticity should have consistent correlation shown in Figure 7. This correlation is linear with excellent coefficient $\left(\mathrm{R}^{2}>0.9\right)$ and the equation $\mathrm{y}=28.842+$ $0.23 \mathrm{x}$. Such a good correlation between strength and dynamic modulus of elasticity proves the uniform consistency of SCC.

The results for ultrasonic velocities are shown in Table 9. Concrete quality classification proposed by Whitehurst (79) categorizes the concrete as "excellent", "good", "doubtful", "poor" and "very poor" for the UPV values of $4500 \mathrm{~m} / \mathrm{s}$ and above, $3500-4500 \mathrm{~m} / \mathrm{s}, 3000-3500 \mathrm{~m} / \mathrm{s}, 2000-3000 \mathrm{~m} / \mathrm{s}$ and $2000 \mathrm{~m} / \mathrm{s}$ and below, respectively. Since measured UPV ranges from 4478 to $4676 \mathrm{~m} / \mathrm{s}$, all mixtures have excellent quality. Table 9 shows that UPV values tend to increase with age, mostly followed a similar trend for compressive strength. However, the rate of UPV development was slower than that concluded in the strength. Overall analysis shows that ultrasonic velocity is increasing during the ageing and with sulfur content decrease. Concerning decrement/increment approach, changes in relations between UPV of SCC with sulfur and the reference SCC are shown in Table 9.

It is evident that the largest decrease $(1.7 \%)$ was at the age of 14 days, for the S10 sample. Also, mutual deviations of UPV per examined series of SCC with sulfur compared to the reference one are small and within the relatively narrow range $(-0.15 \%-1.7 \%)$. Obtained results showed that kind of SCC behavior is induced by several factors: mixture composition, effective w/c ratio, porosity.

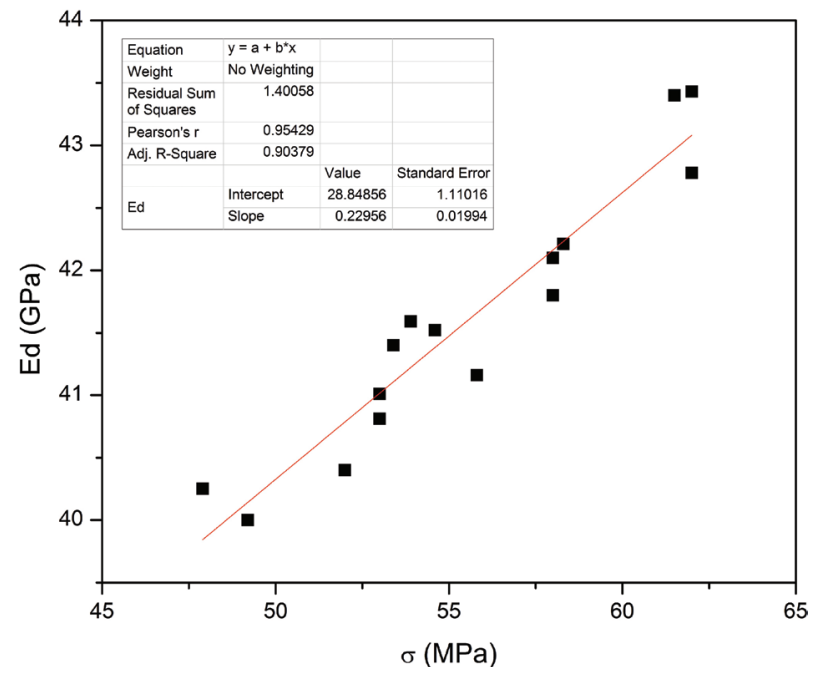

Figure 7. Correlation between compressive strength and dynamic elasticity modulus for SCC samples. 
TABLE 9. Ultrasonic pulse velocity of SCC samples during the ageing

\begin{tabular}{lccccc}
\hline & \multicolumn{5}{c}{ UPV $(\mathbf{m} / \mathbf{s})$ at time of aging (days) } \\
\cline { 2 - 6 } Sample & $\mathbf{7}$ & $\mathbf{1 4}$ & $\mathbf{2 1}$ & $\mathbf{2 8}$ & $\mathbf{1 8 0}$ \\
\hline E & 4525 & 4601 & 4639 & 4657 & 4669 \\
S2 & 4543 & 4598 & 4615 & 4636 & 4673 \\
S5 & 4511 & 4561 & 4602 & 4622 & 4676 \\
S10 & 4478 & 4523 & 4589 & 4607 & 4638 \\
S20 & 4483 & 4540 & 4577 & 4589 & 4630 \\
Standard Deviation (MPa) & 27.60 & 34.60 & 24.00 & 26.15 & 21.51 \\
Mean & 4508 & 4564.5 & 4604.4 & 4622.2 & 4657.2 \\
Maximum & 4543 & 4601 & 4639 & 4657 & 4676 \\
Minimum & 4478 & 4523 & 4577 & 4589 & 4630 \\
Median & 4511 & 4561 & 4602 & 4622 & 4669 \\
\hline
\end{tabular}

Since the mixture compositions mutually differ only in a portion of fillers type, the influence of density of fillers and therefore hardened concrete on UPV is as obvious. Concrete containing a higher content of sulfur has lower UPV value.

Effective w/c ratio is a higher in the samples with higher content of sulfur as discussed before, causing higher porosity and therefore lower UPV value. Also, this can be proved with measured values of true porosity and density (E sample has porosity of $7.9 \%$ while the sample S20 has true porosity of $10.1 \%)$.

Therefore, the higher UPV values of the reference $\mathrm{SCC}$ is probably due to its reduced porosity.

The effect of different fillers on the correlation between compressive strength and UPV was studied by many researchers (80-84). Since the influence of sulfur inclusion on compressive strength and UPV was assessed in this study, the correlation between compressive strength and ultrasonic pulse velocity of SCC at ages of 7, 14, and 28 days is shown in Figure 8. Strong linear correlation degree $\left(\mathrm{R}^{2}=0.83127\right)$ is obtained, so the compressive strength of SCC with sulfur can be accurately predicted.

The results in Figure 8 are relatively close to the values obtained using functional dependencies proposed by Khatib (80) and Liu (81) for SCC with fly ash. On the other side, a similar slope of correlation line and lower ultrasonic velocity for the same compressive strength can be noticed compared to the results of linear correlation obtained by Mardani et al. (82) for SCC with different superplasticizers. The relationship between compressive strength and UPV for SCC with sulfur are lower compared to the values based on correlations for NVC given by Neville and Jones $(83,84)$. Since there are no published results of similar tests for SCC with sulfur, these dependencies have a descriptive approach.

Based on the measured UPV and $\mathrm{E}_{\mathrm{d}}$, the dynamic Poisson ratios $\left(\mu_{d}\right)$ were calculated, Table 10. The

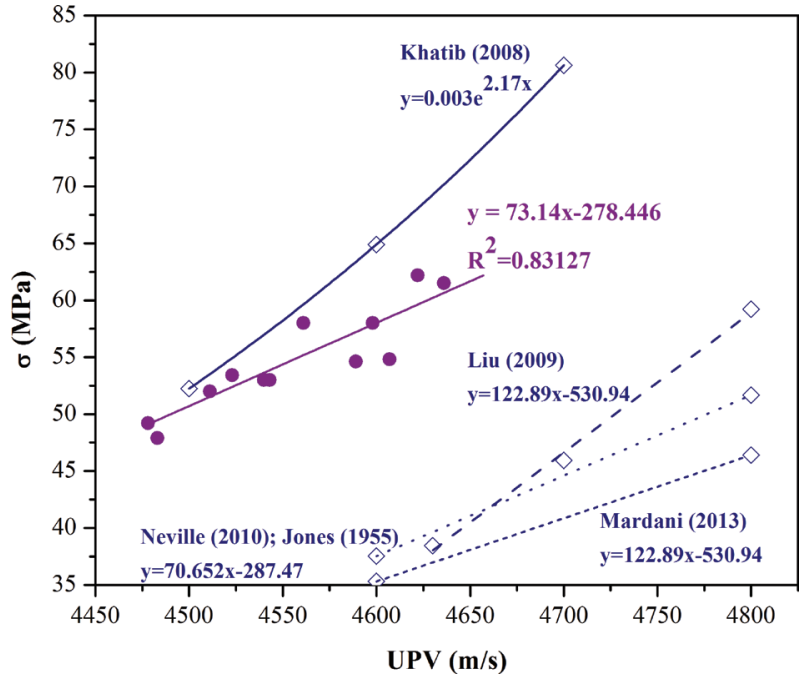

FIGURE 8. Correlation between compressive strength and UPV for the SCC samples.

values are ranging from 0.239 for the reference sample at the age of 7 days up to 0.257 for S20 at the age of 180 days. Measured values of dynamic Poisson ratios for all samples increased with the aging. Comparing the measurements made on studied series, dynamic Poisson coefficients for SCC with sulfur were very close to the calculated values of the reference sample E. Considering those observations, the dynamic Poisson coefficients of limestone and waste sulfur have similar values.

\subsubsection{Microstructure}

Relevant information about microstructure (homogeneity, porosity, properties of hardened cement matrix and the interface between aggregate particles and cementitious materials in hardened SCC) were examined on the reference and S20 
TABLE 10. Results of dynamic Poisson's ratio during the aging

\begin{tabular}{rcccccc}
\hline Dynamic Poisson's ratio, $\boldsymbol{\mu}_{\mathbf{d}}$ & Age (days) & $\mathbf{E}$ & S2 & S5 & S10 & S20 \\
\hline 7 & 0.239 & 0.254 & 0.253 & 0.250 & 0.245 \\
& 14 & 0.250 & 0.252 & 0.248 & 0.243 & 0.250 \\
21 & 0.252 & 0.250 & 0.253 & 0.256 & 0.254 \\
& 28 & 0.248 & 0.245 & 0.250 & 0.254 & 0.255 \\
& 180 & 0.239 & 0.244 & 0.252 & 0.251 & 0.257 \\
\hline
\end{tabular}

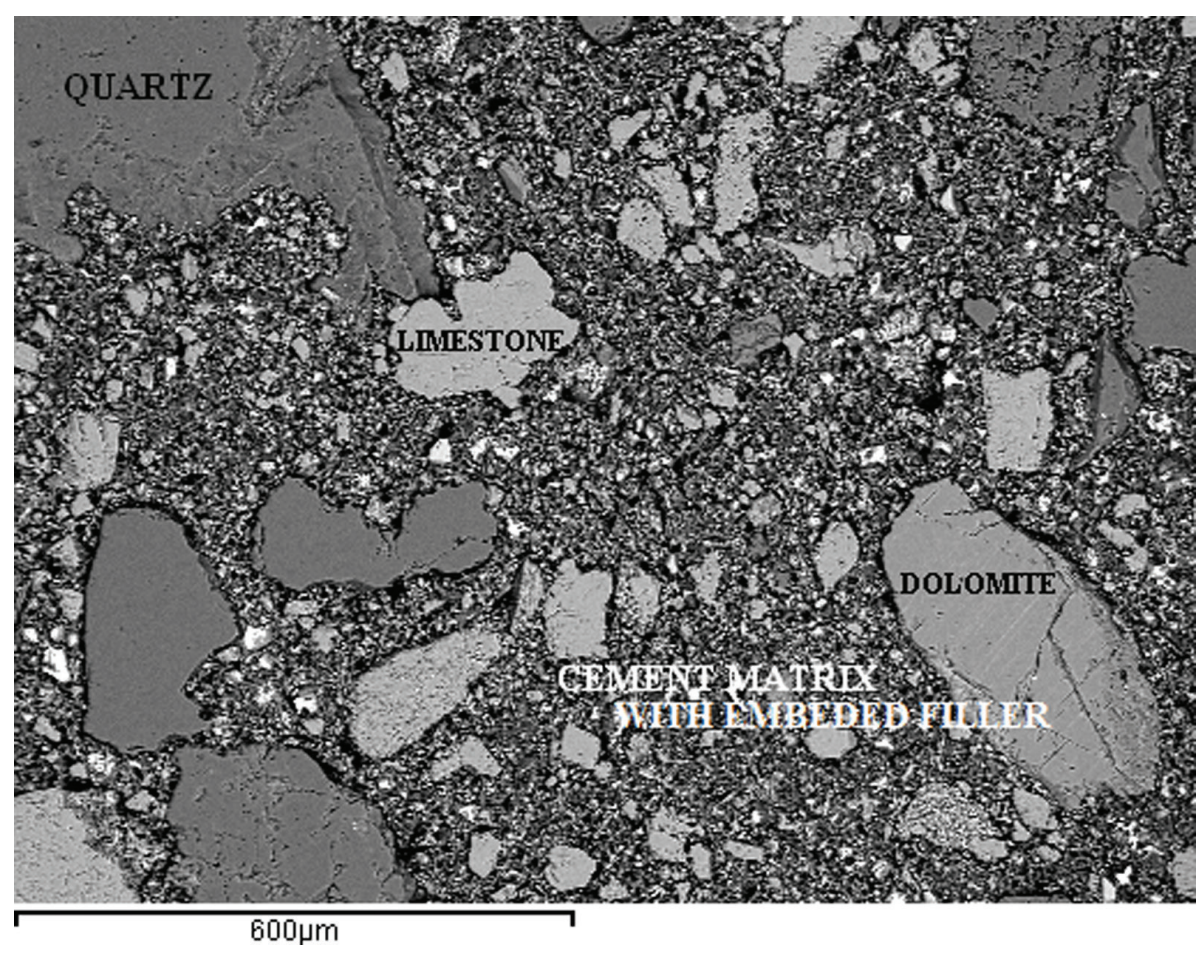

FIGURE 9. Main constituents of SCC.

samples surfaces. Aggregate grains (quartz, quartzite, dolomite), cement matrix, and fillers (limestone and sulfur) can be identified showing the compact internal structure of SCC, Figure 9.

Figure 10 shows the clearly evident interfacial structure between the aggregate particle and cementitious matrix of E and S20 specimens.

According to Figure 10, the surface porosity degree of S20 compared to E did not visually vary. However, in order to confirm the visual appearance, image analysis was applied for measuring the portion of cementitious matrix surface porosity (marked red in Figure 10) and the thickness of Interfacial Transition Zone (ITZ) (marked green in Figure 10). Micrographs of the sample's surface were analyzed by Image-Pro Plus (IPP), a special software program that enables work in all known formats of images and automatically measures, counts, and classifies data on analyzed objects. The program communicates directly with Excel, thus enabling statistical and graphical treatment of data. Results are shown in Table 11.

The interfacial transition zones are the weakest bond of concrete and the cracks development commonly reveal in the interfacial zone between the aggregate particles and cementitious matrix (85). Therefore, ITZ thickness measuring at about 30 spots between aggregate grains and matrix and average values in both specimens was done by IPP and it was less than $5 \mu \mathrm{m}$. More precisely, it is evident that ITZ of S20 is thinner than in E. Difference between surface porosity of two examined samples is very small. Considering the Image Pro Plus results (Table 11), the number of pores in S20 is smaller while the porosity is higher than in E. These results correspond to the compressive strength decrease in the case of S20 compared with E. The presence of soft sulfur particles additionally contributes to compressive strength decrease. 

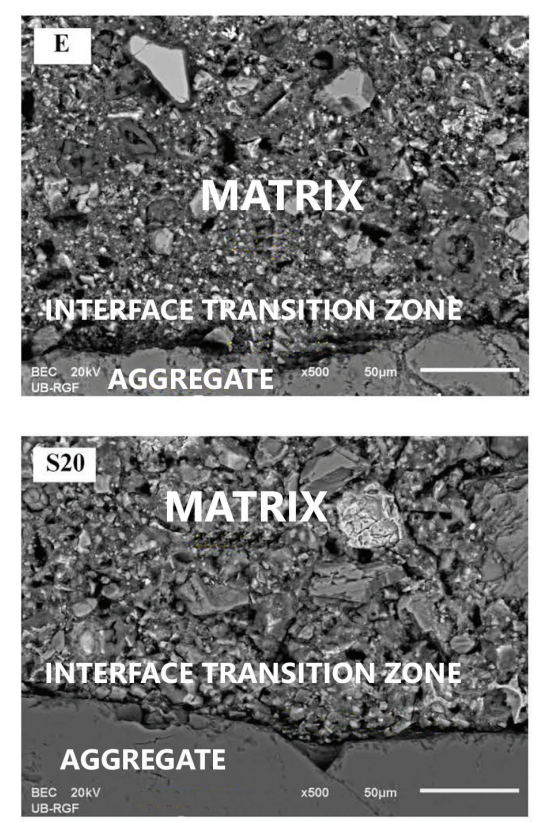

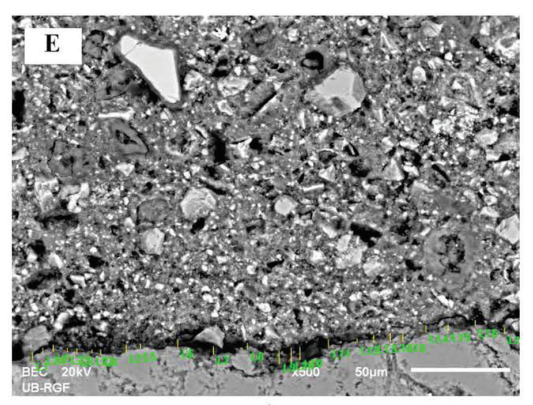

a)

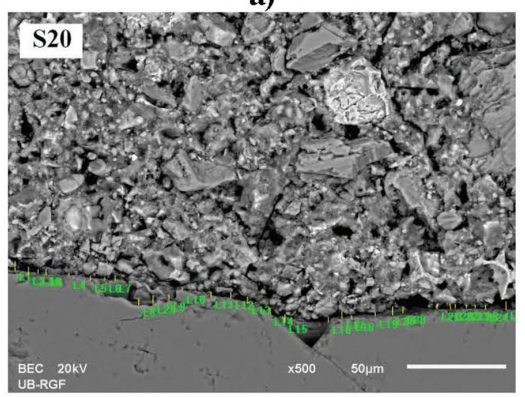

b)
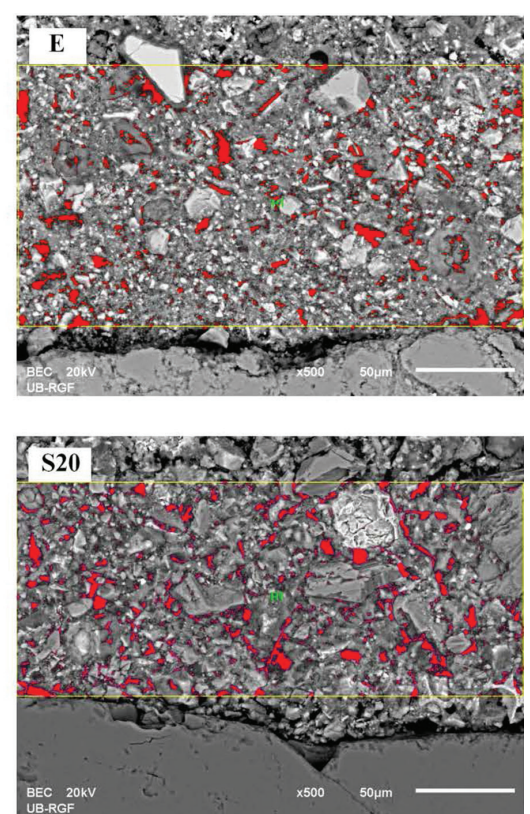

FIGURE 10. SEM micrographs of the SCC: (a) sample E; (b) sample S20.

TABLE 11. Results of ITZ thickness, surface matrix porosity, true density and total porosity

\begin{tabular}{lccccc}
\hline Specimen & Thickness of ITZ & Counted object number & Surface matrix porosity & True density & Total porosity \\
\hline E & $3.62 \mu \mathrm{m}$ & 1998 & $5.85 \%$ & $2.626 \mathrm{~g} / \mathrm{cm}^{3}$ & $7.9 \%$ \\
S20 & $2.74 \mu \mathrm{m}$ & 1476 & $7.043 \%$ & $2.604 \mathrm{~g} / \mathrm{cm}^{3}$ & $10.1 \%$ \\
\hline
\end{tabular}

With the aim of characterizing the distribution of phases in the matrix, EDS analysis was performed on several surface places. Appropriate EDS analysis results for the sample shown in Figure 11 are given in Table 12.

Based on the results, the matrix has following composition: S grains (Spectrum 1) and quartzl sand (Spectrum 5) while the Spectrums 2, 3, and 4 indicate the presence of $\mathrm{CH}$ and $\mathrm{CSH}$ phases. The contact zone between sulfur grains and the surrounding matrix (Spectrum 2) remained almost chemically unchanged since EDS analysis shows slightly higher sulfur content with other similar constituents. On the other side, the contact zone between quartz and the matrix (Spectrum 4) indicates higher Si content.

On the basis of image analysis, it can be concluded that $\mathrm{E}$ shows a presence of higher content of smaller pores, while S20 has a lower content of larger pores, which cannot be visually distinguished. According to $\mathrm{Hg}$ porosimetry, further information regarding pore size was obtained. The measurements showed that sample S20 had higher average pore size diameter $(45.8 \mathrm{~nm})$ than $\mathrm{E}(43.5 \mathrm{~nm})$, which approved the image analysis. This measurement also approved discussion regarding effective w/c ratio (higher porosity of S20).

Sulfur in an alkaline matrix such as cement paste is a chemically stable material $(86,87)$. Considering the SEM and EDS analysis, it can be concluded that the reaction of sulfur with hydrated cementitious phases does not happen. Therefore, unlike sulfates, the sulfur can be considered as a chemically inert component in such mixtures, so the sulfate attack phenomenon is practically impossible in these conditions. Even, by visual inspection of the samples sulfur can be detected with its characteristic yellow color.

Mapping by elements $\mathrm{S}, \mathrm{Ca}$, and $\mathrm{Si}$ (qualitative analysis) was performed at several matrix surface places, Figure 12. Based on the results, it is evident that main particles of the matrix are uniformly distributed showing good homogeneity of components inside the matrix. Regarding the dispersion of limestone and sulfur performed at several matrix surface places, grouping/clustering of ground particles was not observed and good distribution of all matrix components is evident. 


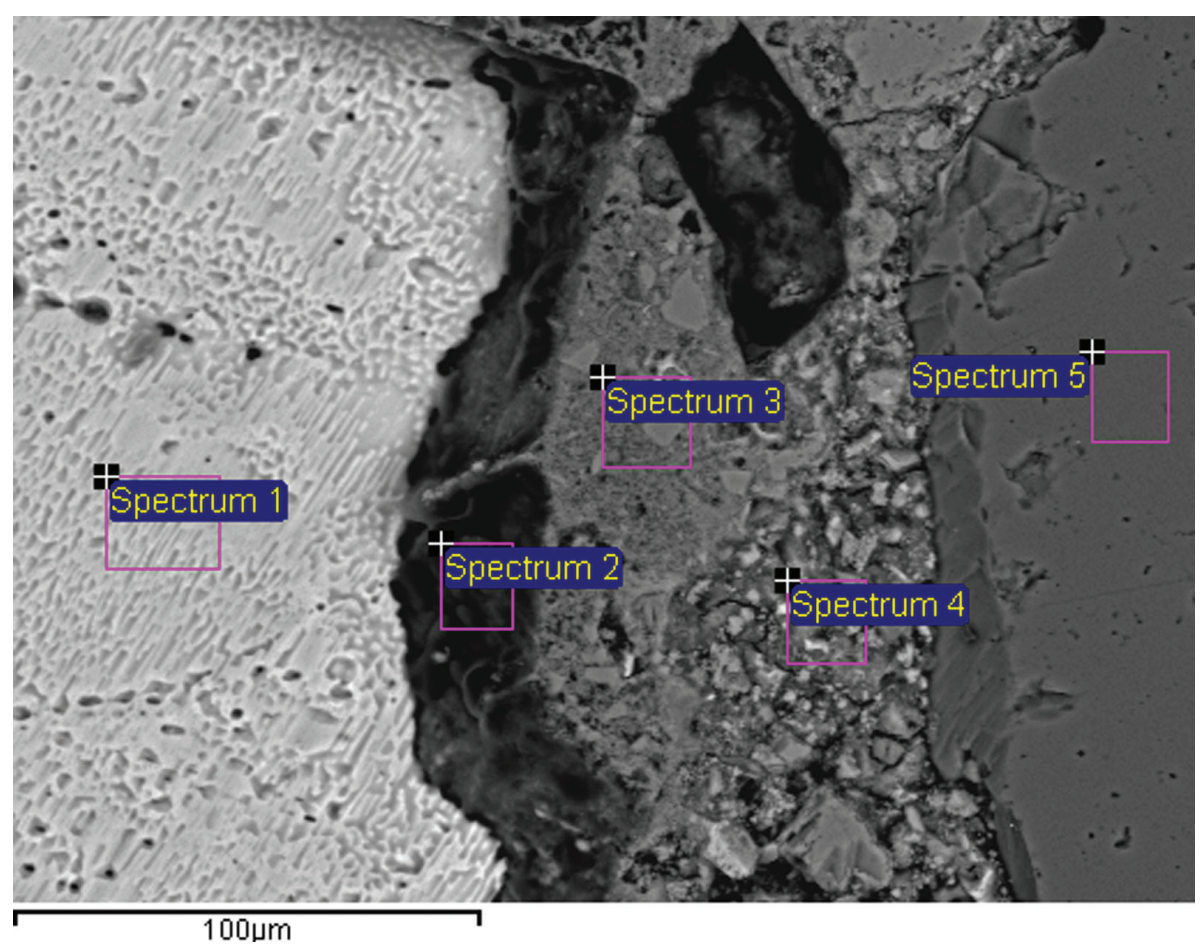

FIGURE 11. Characteristic positions of EDS analysis in the matrix of S20.

TABLE 12. EDS analysis of characteristic positions in SCC matrix

\begin{tabular}{|c|c|c|c|c|c|c|c|c|c|c|}
\hline \multirow[b]{2}{*}{ Position } & \multicolumn{10}{|c|}{ Content $($ weight $\%)$} \\
\hline & $\mathbf{O}$ & Mg & Al & $\mathbf{S i}$ & $\mathbf{S}$ & $\mathrm{Cl}$ & $\mathbf{K}$ & $\mathrm{Ca}$ & $\mathrm{Fe}$ & Total \\
\hline Spectrum 1 & 0.00 & 0.00 & 0.00 & 0.00 & 100.00 & 0.00 & 0.00 & 0.00 & 0.00 & 100.00 \\
\hline Spectrum 2 & 57.20 & 0.00 & 0.69 & 5.19 & 8.78 & 0.75 & 0.49 & 26.90 & 0.00 & 100.00 \\
\hline Spectrum 3 & 55.30 & 0.64 & 1.55 & 5.30 & 3.14 & 0.17 & 0.54 & 32.48 & 0.88 & 100.00 \\
\hline Spectrum 4 & 54.40 & 1.64 & 3.05 & 8.20 & 3.50 & 0.00 & 0.00 & 27.51 & 1.70 & 100.00 \\
\hline Spectrum 5 & 54.31 & 0.00 & 0.00 & 45.69 & 0.00 & 0.00 & 0.00 & 0.00 & 0.00 & 100.00 \\
\hline Mean & 44.24 & 0.46 & 1.06 & 12.88 & 23.08 & 0.18 & 0.20 & 17.38 & 0.51 & 100.00 \\
\hline Std. deviation & 24.76 & 0.72 & 1.28 & 18.58 & 43.11 & 0.33 & 0.28 & 16.01 & 0.76 & - \\
\hline Max. & 57.20 & 1.64 & 3.05 & 45.69 & 100.00 & 0.75 & 0.54 & 32.48 & 1.70 & - \\
\hline Min. & 0.00 & 0.00 & 0.00 & 0.00 & 0.00 & 0.00 & 0.00 & 0.00 & 0.00 & - \\
\hline
\end{tabular}

\section{CONCLUSIONS}

The influence of waste sulfur as a partial substitution for usually used filler limestone powder on the properties of SCC was studied in this paper by comparing five series with different compositions. The main conclusions of this research regarding fresh and hardened properties of SCC are presented below.

According to the EFNARC, all tested samples with sulfur meet the requirements of fresh SCC properties. Flowability tests show an increase in SF values up to a certain sulfur content most likely due to the values of specific surface area and hydrophobicity of sulfur and limestone, both having the same effect on this property. Sulfur has a lower specific surface area and higher hydrophobicity than limestone, leaving the higher content of free water inside the fresh mixtures, thus producing reduced yield stress and friction among particles and therefore better flowability. The flow rate characterized by t500 and tv values showed no significant change with respect to sulfur content, as well as the height ratio $\mathrm{H} 2 / \mathrm{H} 1$, segregation resistance, and entrained air content. The bulk density showed small reduction, up to $0.9 \%$, caused by sulfur presence that can be explained by lower specific gravity of ground sulfur compared with limestone powder. 


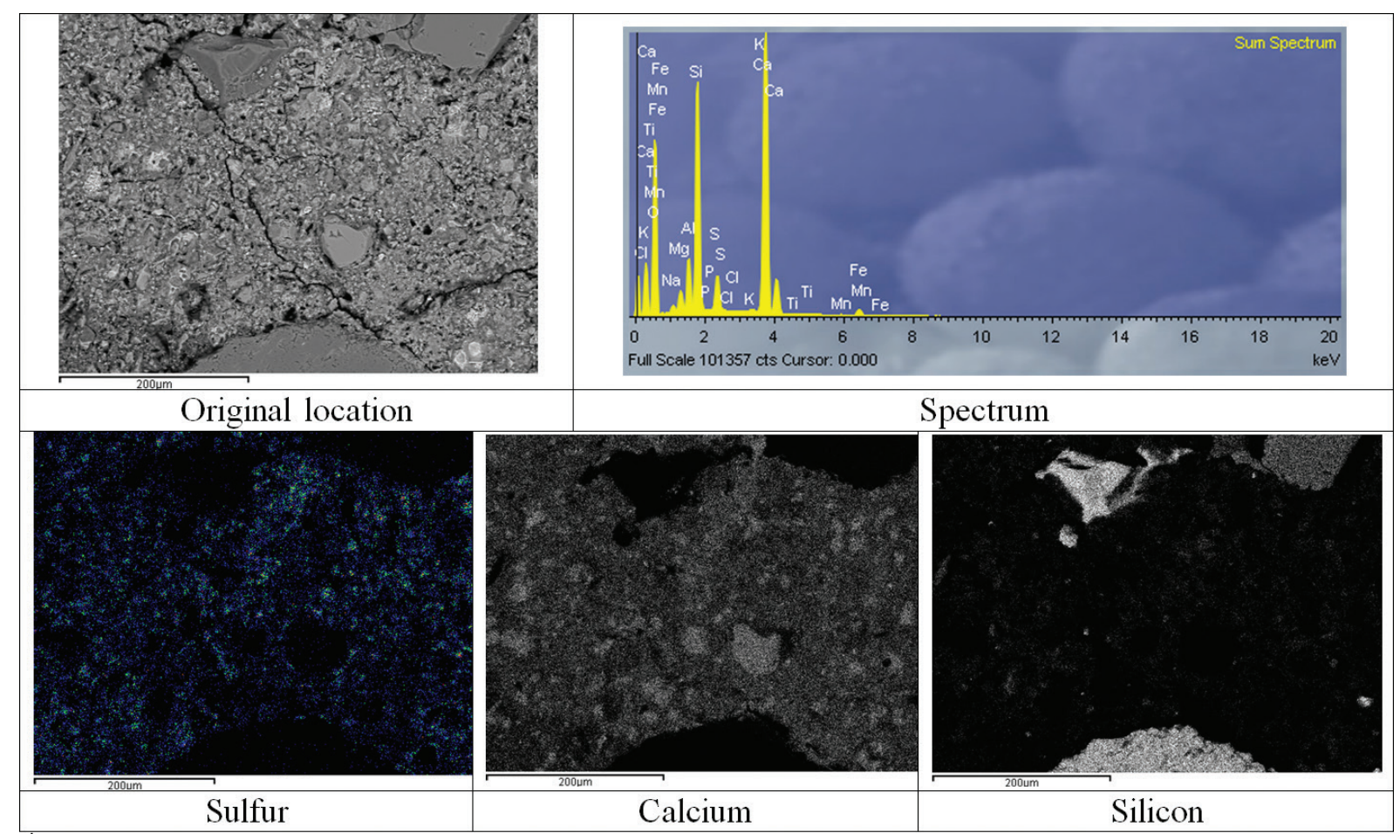

FIGURE 12. Mapping result of SCC S20.

Regarding the hardened state of mixtures, the compressive strength of SCC with sulfur was lower compared with the reference sample, at all ages. However, compressive strength values after 28 days of ageing (54-62 $\mathrm{MPa}$ ) show that all mixtures can be used in common structural applications. Flexural strength decrease while the adhesion strength increase with increasing of the sulfur content in sample, so the use of sulfur has no negative influence on the adhesive strength regardless of the used dolly diameter. Sulfur addition resulted in ultrasonic pulse velocity decrease, regardless of its content and age, as well as dynamic modulus of elasticity. Samples containing a higher content of sulfur showed lower UPV values, due to the lower density of sulfur, and due to higher content of free water resulting in higher porosity of these samples. According to the SEM analysis, slight surface porosity increase was noticed for the sample S20 which was in accordance with the experimental compressive strength results. Considering the SEM and EDS analysis, it can be concluded that the reaction of sulfur with hydrated cementitious phases does not happen, proving that sulfur in an alkaline matrix such as cement paste is a chemically stable material, that is chemically inert component in such mixtures, so the sulfate attack is practically impossible in these conditions. Therefore, using sulfur as a waste byproduct has economic benefits, as a replacement for limestone in SCC.
Above conclusions proved that by valorization of secondary sulfur from the oil refining process for the SCC production the waste was turned into valuable material. Having in mind that use of supplementary cementing materials and fillers such as: fly ash, silica fume, combustion products of various industrial processes is increasing, future studies should address binary and ternary mixtures, incorporating two or three fillers in the SCC whereby one of them is sulfur. Also, the durability of such SCC mixtures should be investigated more in the future, having in mind the lack of data regarding this subject in today's scientific literature.

\section{ACKNOWLEDGMENTS}

This work was supported by the Ministry of Education, Science and Technological Development of the Republic of Serbia [grant numbers III 45012, TR 33007 and TR 36017].

\section{REFERENCES}

1. Marinković, S.B. (2013) Life cycle assessment (LCA) aspects of concrete in Eco-Efficient Concrete, A volume in Woodhead Publishing Series in Civil and Structural Engineering (Edited by Pacheco- Torgal, F.; Jalali, S.; Labrincha, J.; John, V.M.). Woodhead Publishing Limited, 45-80. https://doi.org/10.1533/9780857098993.1.45.

2. Marinković, S.B.; Ignjatović, I.S.; Radonjanin, V.S. (2013) Life-cycle assessment (LCA) of concrete with recycled aggregates (RAs) in Handbook of Recycled Concrete and 
Demolition Waste, Woodhead Publishing Series in Civil and Structural Engineering. (Edited by Pacheco- Torgal, F.; Tam, V.W.Y; Labrincha, J.; Ding, Y.; de Brito, J.). Woodhead Publishing Limited, 569-604. https://doi.org/1 0.1533/9780857096906.4.569.

3. Savić, A.R. (2015) Investigation of the properties of fresh and hardened self-compacting concrete with mineral additions based on industrial by-products. PhD Thesis. University of Belgrade, Faculty of Civil Engineering, Belgrade, (2015).

4. Okamura, H.; Ouchi, M. (2003) Self-Compacting Concrete. J. Adv. Concr. Technol. 1 [1], 5-15. https://doi.org/10.3151/ jact.1.5.

5. Ouchi, M. (2001) Self-compacting concrete: development, applications and key technologies. Proceedings of $26^{\text {th }}$ Conference on Our World in Concrete \& Structures. Singapore, 89-97. https://pdfs.semanticscholar.org/d513/5 39eb69ca9060ed535293c847cccc84fe1bd.pdf.

6. Silva, Y.F.; Robayo, R.A.; Mattey, P.E.; Delvasto, S. (2016) Properties of self-compacting concrete on fresh and hardened with residue of masonry and recycled concrete, Constr. Build. Mater. 124, 639-644. https://doi.org/ 10.1016/j.conbuildmat.2016.07.057.

7. ACI 238.1R-08 (2008) Report on Measurements of Workability and Rheology of Fresh Concrete, American Concrete Institute. (2008).

8. European Guidelines for Self-Compacting Concrete: Specification, Production and Use (2005) European Project Group. (2005).

9. Okamura, H.; Ouchi, M. (1999) Self-compacting concrete - Development, present and future. Proceedings of $1^{\text {st }}$ International RILEM Symposium on Self-Compacting Concrete, Stockholm, 3-14.

10. Self compacting concrete-State-of-the-art report of RILEM TC 174-SCC (2000) Skarendahl A, Petersson, O, editors, France: RILEM Publications S.A.R.L, (2000).

11. Nehdi, M.L.; Pardhan, M.; Koshowski, S. (2004) Durability of self-consolidating concrete incorporating high-volume replacement composite cements. Cement. Concr. Res. 34 [11], 2103-2112. https://doi.org/10.1016/j.cemconres.2004.03.018.

12. Ozawa, K. (2001) Utilization of new concrete technology in construction project - Future prospects of self-compacting concrete. Proceedings of $2^{\text {nd }}$ International RILEM Symposium on Self-Compacting Concr. Tokyo, 55-62.

13. Walraven, J.C. (1998) The development of self-compacting concrete in the Netherlands. International Workshop on Self-compacting Concrete. Kochi, Japan, 87-96.

14. Ranjibar, M.M.; Madandoust, R.; Mousari, S.Y.; Yosefi, S. (2013) Effects of natural zeolite on the fresh and hardened properties of self-compacted concrete. Constr. Build. Mater. 47, 806-813. https://doi.org/10.1016/j.conbuildmat. 2013.05.097.

15. Rozas, F.; Castillo, A.; Martínez, I.; Castellote, M. (2015) Guidelines for assessing the valorization of a waste into cementitious material: dredged sediment for production of self compacting concrete. Mater. Construcc. 65 [319], e057. http://dx.doi.org/10.3989/mc.2015.10613.

16. Felekoglu, B.; Tosun, K.; Baradan, B.; Altun, A.; Uyulgan, B. (2006) The effect of fly ash and limestone fillers on the viscosity and compressive strength of self-compacting repair mortars. Constr. Build. Mater. 36 [9], 1719-1726. https://doi.org/10.1016/j.cemconres.2006.04.002.

17. Sahmaran, M.; Christianto, H.A.; Yaman, I.O. (2006) The effect of chemical admixtures and mineral additives on the properties of self-compacting mortars. Cement. Concr. Comp. 28 [5], 432-440. https://doi.org/10.1016/j.cemconcomp.2005.12.003

18. Nielsen, C.V.; Glavind, M. (2007) Danish experience with a decade of green concrete. J. Adv. Concr. Technol. 5 [1], 3-12. https://doi.org/10.3151/jact.5.3.

19. Fib Bulletin 67: Guidelines for green concrete structures. (2012) International Federation for Structural Concrete (fib). 1562-3610. (2012).

20. Burgos, D; Guzmán, A. Hossain, K.M.A; Delvasto, S. (2017) The use of a volcanic material as filler in self-compacting concrete production for lower strength applications.
Mater. Construcc. 67 [325], e111. http://dx.doi.org/10.3989/ mc.2017.09315.

21. Taieb, F.; Belas, N.; Mesbah, H.A. (2019) Influence of treated mud on free shrinkage and cracking tendency of self-compacting concrete equivalent mortars. Mater. Construcc. 69 [334], e186. https://doi.org/10.3989/ mc.2019.02318.

22. Weidema, B.P. (2014) Example -sulfur from refineries. Version: 2015-01-15. https://consequential-lca.org/clca/ by-products-recycling-and-waste/not-fully-utilised-byproduct/example-sulfur-from-refineries/ (last accessed 11.11.2019.).

23. Gracia, V; Vàzquez, E; Cramona, S. (2004) Utilization of by-produced sulfur for the manufacture of unmodified sulfur Concr. International RILEM Conference on the Use of Recycled Materials in Buildings and Structures, Barcelona, Spain, 1054-1063.

24. World Business Council for Sustainable Development (2009) Cement Industry Energy and $\mathrm{CO}_{2}$ Performance, Getting the Numbers Right. http://docs.wbcsd.org/2009/06/ CementIndustryEnergyAndCO2Performance.pdf.

25. Vlahović, M. (2012) Synthesis of secondary sulfur based concrete and examining its durability in aggressive environment. PhD Thesis. University of Belgrade. Faculty of Technology and Metallurgy, Belgrade (2012).

26. McBee, W.C. Sullivan, T.A.; Jong, B.W. (1983) Industrial Evaluation of Sulfur concrete in Corrosive Environments. United States Department of the Interior (1983).

27. Mohamed, A.M.O.; El Gamal, M.M. (2010) Sulfur concrete for the construction industry, a sustainable development approach. J. Ross Publishing (2010).

28. Vlahović, M.; Martinović, S.; Boljanac, T.; Jovanić, P.; Volkov-Husović, T. (2011) Durability of sulfur concrete in various aggressive environments. Constr. Build. Mat. 25 [10], 3926-3934. https://doi.org/10.1016/j.conbuildmat. 2011.04.024.

29. Vlahović, M.; Jovanić, P.; Martinović, S.; Boljanac, T.; Volkov-Husović, T. (2013) Quantitative evaluation of sulfur-polymer matrix composite quality. Compos. Part B: eng. 44 [1], 458-466. https://doi.org/10.1016/j.compositesb. 2012.04.005.

30. Vlahović, M.; Savić, M.; Martinović, S.; Boljanac, T.; Volkov-Husović, T. (2012) Use of image analysis for durability testing of sulfur concrete and Portland cement concrete. Mater: Des. 34, 346-354. https://doi.org/10.1016/j. matdes.2011.08.026.

31. Mattus, C. H. Mattus, A. J. (1994) Evaluation of sulfur polymer cement as a waste form for the immobilization of low-level radioactive or mixed waste. Chemical Technology Division, U.S. Department of Energy, Office of Technology Development. (1994).

32. Filipović, I.; Lipanović, S. (1979) Opća i anorganska kemija. III izdanje. Školska knjiga, Zagreb (1979).

33. Eckert, B. (2003) Molecular Spectra of Sulfur Molecules and Solid Sulfur Allotropes, pp. 31-98. In: Steudel, Ralf. (Ed.) Elemental Sulfur and Sulfur-Rich Compounds II, Springer (2003).

34. De Nicolo, B.; Pani, L.; Mistretta, F. (2006) Profit of Medium-low Strength Self Compacting Concr. Proceedings of the $2^{\text {nd }}$ International Congress. Naples, Italy, Paper ID $13-37$.

35. SRPS EN 933-1:2013 Tests for geometrical properties of aggregates - Part 1: Determination of particle size distribution - Sieving method.

36. SRPS B.B8.036:1982 Crushed aggregate - Determination of fine particles with the wet sieve analysis.

37. SRPS B.B8.044:1982 Natural and crushed stone aggregate - Test for freezing resistance.

38. SRPS B.B8.042:1984 Natural and crushed aggregate Chemical analysis of aggregares for concretes and mortars.

39. SRPS ISO 6783:1999 Coarse aggregates for concrete Determination of particle density and water absorption Hydrostatic balance method.

40. SRPS ISO 7033:1999 Fine and coarse aggregates for concrete - Determination of the particle mass-per-volume and water absorption - Pycnometer method. 
41. SRPS ISO 6782:1999 Aggregates for concrete Determination of bulk density.

42. SRPS B.B8.045:1978 Testing of natural rock - Testing of natural and crushed aggregate rock by machine "Los Angeles"'

43. SRPS B.B8.033:1994 Mineral aggregate - Determination of crushability by compression in cylinder.

44. SRPS B.B2.010:1986 Aggregate for concrete - Technical requirements.

45. SRPS B.B2.009:1986 Raw materials for production of aggregates for concrete- Technical requirements.

46. SRPS B.C8.023: 1982 Cements. Methods of testing cements - physical tests.

47. SRPS EN 196-6:2019 Methods of testing cement - Part 6: Determination of fineness.

48. SRPS EN 196-3:2017 Methods of testing cement - Part 3: Determination of setting times and soundness.

49. SRPS EN 196-2:2015 Method of testing cement-Part 2: Chemical analysis of cement.

50. SRPS EN 1936:2009 Natural stone test methods Determination of real density and apparent density, and of total and open porosity.

51. SRPS EN 13755:2009 Natural stone test methods Determination of water absorption at atmospheric pressure.

52. SRPS EN 1926:2010 Natural stone test methods Determination of uniaxial compressive strength.

53. SRPS EN 12372:2009 Natural stone test methods Determination of flexural strength under concentrated load.

54. SRPS EN 14157:2017 Natural stone test methods Determination of the abrasion resistance.

55. SRPS EN 12371:2014 Natural stone test methods Determination of frost resistance

56. SRPS EN 206-1:2011 Concrete - Part 1: Specification performance, production and conformity.

57. SRPS EN 12350-10:2012 Testing fresh concrete - Part 10: Self-compacting concrete - L box test.

58. SRPS EN 12350-11:2012; Testing fresh concrete - Part 11: Self-compacting concrete - Sieve segregation test.

59. SRPS EN 12350-6:2010 Testing fresh concrete - Part 6: Density.

60. SRPS EN 12350-7:2010 Testing fresh concrete - Part 7: Air content - Pressure methods.

61. SRPS EN 12390-3:2010 Testing hardened concrete - Part 3: Compressive strength of test specimens.

62. SRPS EN 12390-5:2010 Testing hardened concrete - Part 5: Flexural strength of test specimens.

63. SRPS EN 1542:2010 Products and systems for the protection and repair of concrete structures - Test methods Measurement of bond strength by pull-off.

64. SRPS U.M1.026:1993 Concrete - Determination of the dynamic modulus of elasticity and Poisson's ratio.

65. SRPS U.M1.042:1998 Concrete, hardened - Determination of ultrasonic pulse velocity.

66. Kasemsamrarn, N.; Tangtermsirikul, S. (2005) A design approach for self-compacting concrete based on deformability, segregation resistance and passing ability models. First International RILEM Symposium on Design, Perofmance and Use of Self-Consolidating Concrete SCC, 47-54.

67. Benjeddou, O.; Soussi, C.; Jedidi, M.; Benali, M. (2017) Experimental and theoretical study of the effect of the particle size of limestone fillers on the rheology of selfcompacting concrete. J. Build. Eng. 10, 32-41. https://doi. org/10.1016/j.jobe.2017.02.003

68. Mahoutian, M.; Shekarachi, M. (2015) Effect of inert and pozzolanic materials on flow and mechanical properties of self-compacting concrete. J. Mater. 2015 [239717], 1-11. https://doi.org/10.1155/2015/239717

69. Dragica, J.; Dimitrije, Z.; Aleksandar, S.; Aleksandar, R. (2014) Statistical analysis of concrete quality testing results. Build. Mater. Struct. 57 [1], 45-52. http://dx.doi. org/10.5937/grmk1401045J.

70. Iffat, S. (2015) Relation between density and compressive strength of hardened Concr. Concrete Research Letters 6 [4], 182-189. www.challengejournal.com/index.php/cjcrl/ article/download/197/156.

71. Muravljov, M. (2010) Osnovi teorije i tehnologije betona. Gradjevinska knjiga Stylos, Beograd (2010).

72. Newman, J (2003) Advanced Concrete Technology: Processes. Elsevier, Butterworth-Heinemann, Oxford (2013).

73. Montero, J.; Laserna S. (2017) Influence of effective mixing water in recycled concrete. Const. Build. Mater. 132. 343352. https://doi.org/10.1016/j.conbuildmat.2016.12.006.

74. Alyousef, R.; Benjeddou, O.; Soussi, C.; Khadimallah, M.A. Mohamed, A.M. (2019) Effects of incorporation of marble powder obtained by recycling waste sludge and limestone powder on rheology, compressive strength, and durability of self-compacting concrete. Adv. Mater. Sci. Eng. 2019. 1-15. https://doi.org/10.1155/2019/4609353.

75. Pereira, E.; De Medeiros, M.H.F. (2012) Pull Off test to evaluate the compressive strength of concrete: an alternative to Brazilian standard techniques, Rev. IBRACON de Estrut. Mater. 5 [6], 775-780. http://dx.doi.org/10.1590/ S1983-41952012000600003.

76. Martinović, S.; Vlahović, M.; Majstorović, J.; VolkovHusović, T. (2016) Anisotropy analysis of low cement concrete by ultrasonic measurements and image analysis, $\mathrm{Sci}$. Sint. 48 [1], 57-70. https://doi.org/10.2298/SOS1601057M.

77. Martinović, S.; Vlahović, M.; Boljanac, T.; Majstorović, J.; Volkov-Husović, T. (2014) Influence of sintering temperature on thermal shock behavior of low cement high alumina refractory concrete. Compos. Part B-Eng. 60, 400412. https://doi.org/10.1016/j.compositesb.2013.12.077.

78. Hayati, E.Z.; Moradi, O.M.; Kakroudi, M.G. (2013) Investigation the effect of sintering temperature on Young's modulus evaluation and thermal shock behavior of a cordierite-mullite based composite. Mater. Design. 45, 571-575. https://doi.org/10.1016/j. matdes.2012.08.014.

79. Whitehurst, E.A. (1951) Soniscope tests concrete structure. ACI J. Proceed. 47 [2], 433-444. https://doi. org/10.14359/12004.

80. Khatib, J.M. (2008) Performance of self-compacting concrete containing fly ash. Constr. Build. Mater. 22 [9], 1963-1971. https://doi.org/10.1016/j.conbuildmat.2007.07.011.

81. Liu, M. (2009) Wider application of additions in selfcompacting concrete. PhD thesis. Department of Civil, Environmental and Geomatic Engineering. University College London, (2009).

82. Mardani-Aghabaglou, A.; Tuyan, M.; Yılmaz, G.; Arı̈z, Ö.; Ramyar, K. (2013) Effect of different types of superplasticizer on fresh, rheological and strength properties of selfconsolidating concrete. Constr. Build. Mater. 47, 1020-1025. https://doi.org/10.1016/j.conbuildmat.2013.05.105.

83. Jones, R. (1949) The non-destructive testing of concrete. Mag. Concr. Res. 1 [2], 67-78. https://doi.org/10.1680/ macr.1949.1.2.67.

84. Neville, A.M.; Brooks, J.J. (2010) Concrete Technology, Second edition. Pearson Education Limited, England (2010).

85. Akçäzoğlu, K. (2013) Microstructural examination of concrete exposed to elevated temperature by using plane polarized transmitted light method. Constr. Build. Mater. 48, 772-779. https://doi.org/10.1016/j.conbuildmat.2013.06.059.

86. Thomas, C; Cimentada, A. Polanco, J.A; Setién, J. Méndez, D.; Rico, J. (2013) Influence of recycled aggregates containing sulphur on properties of recycled aggregate mortar and concrete. Compos. Part B-Eng. 45 [1], 474485. https://doi.org/10.1016/j.compositesb.2012.05.019.

87. Lin, S.L.; Cross, W.H.; Chian, E.S.K.; Lai, J.S.; Giabbai, M.; Hung, C.H. (1996) Stabilization and solidification of lead in contaminated soils. J. Hazard. Mater. 48 [1-3], 95-110. https://doi.org/10.1016/0304-3894(95)00143-3. 